\title{
Significant enhancements of nitrogen oxides, black carbon, and ozone in the North Atlantic lower free troposphere resulting from North American boreal wildfires
}

\author{
M. Val Martín, ${ }^{1}$ R. E. Honrath, ${ }^{1}$ R. C. Owen, ${ }^{1}$ G. Pfister, ${ }^{2}$ P. Fialho, ${ }^{3}$ and F. Barata ${ }^{3}$
}

Received 18 May 2006; revised 13 September 2006; accepted 4 October 2006; published 7 December 2006.

[1] Extensive wildfires burned in northern North America during summer 2004, releasing large amounts of trace gases and aerosols into the atmosphere. Emissions from these wildfires frequently impacted the PICO-NARE station, a mountaintop site situated 6-15 days downwind from the fires in the Azores Islands. To assess the impacts of the boreal wildfire emissions on the levels of aerosol black carbon (BC), nitrogen oxides and $\mathrm{O}_{3}$ downwind from North America, we analyzed measurements of $\mathrm{CO}, \mathrm{BC}$, total reactive nitrogen oxides $\left(\mathrm{NO}_{y}\right), \mathrm{NO}_{x}\left(\mathrm{NO}+\mathrm{NO}_{2}\right)$ and $\mathrm{O}_{3}$ made from June to September 2004 in combination with MOZART chemical transport model simulations. Long-range transport of boreal wildfire emissions resulted in large enhancements of $\mathrm{CO}, \mathrm{BC}, \mathrm{NO}_{y}$ and $\mathrm{NO}_{x}$, with levels up to $250 \mathrm{ppbv}, 665 \mathrm{ng} \mathrm{m}^{-3}$, $1100 \mathrm{pptv}$ and $135 \mathrm{pptv}$, respectively. Enhancement ratios relative to $\mathrm{CO}$ were variable in the plumes sampled, most likely because of variations in wildfire emissions and removal processes during transport. Analyses of $\Delta \mathrm{BC} / \Delta \mathrm{CO}, \Delta \mathrm{NO}_{y} / \Delta \mathrm{CO}$ and $\Delta \mathrm{NO}_{x} / \Delta \mathrm{CO}$ ratios indicate that $\mathrm{NO}_{y}$ and $\mathrm{BC}$ were on average efficiently exported in these plumes and suggest that decomposition of PAN to $\mathrm{NO}_{x}$ was a significant source of $\mathrm{NO}_{x}$. High levels of $\mathrm{NO}_{x}$ suggest continuing formation of $\mathrm{O}_{3}$ in these well-aged plumes. $\mathrm{O}_{3}$ levels were also significantly enhanced in the plumes, reaching up to $75 \mathrm{ppbv}$. Analysis of $\Delta \mathrm{O}_{3} / \Delta \mathrm{CO}$ ratios showed distinct behaviors of $\mathrm{O}_{3}$ in the plumes, which varied from significant to lower $\mathrm{O}_{3}$ production. We identify several potential reasons for the complex effects of boreal wildfire emissions on $\mathrm{O}_{3}$ and conclude that this behavior needs to be explored further in the future. These observations demonstrate that boreal wildfire emissions significantly contributed to the $\mathrm{NO}_{x}$ and $\mathrm{O}_{3}$ budgets in the central North Atlantic lower free troposphere during summer 2004 and imply large-scale impacts on direct radiative forcing of the atmosphere and on tropospheric $\mathrm{NO}_{x}$ and $\mathrm{O}_{3}$.

Citation: Val Martín, M., R. E. Honrath, R. C. Owen, G. Pfister, P. Fialho, and F. Barata (2006), Significant enhancements of nitrogen oxides, black carbon, and ozone in the North Atlantic lower free troposphere resulting from North American boreal wildfires, J. Geophys. Res., 111, D23S60, doi:10.1029/2006JD007530.

\section{Introduction}

[2] Boreal wildfires are large sources of reactive trace gases and aerosols in the atmosphere [e.g., Goode et al., 2000; Andreae and Merlet, 2001]. The large amounts of trace gases and aerosols emitted by boreal forest fires are subject to long-range transport, with the potential to affect air quality on regional to global scales. Boreal wildfire plumes have been detected over continental [Wotawa and Trainer,

\footnotetext{
${ }^{1}$ Department of Civil and Environmental Engineering, Michigan Technological University, Houghton, Michigan, USA.

${ }^{2}$ Atmospheric Chemistry Division, National Center for Atmospheric Research, Boulder, Colorado, USA.

${ }^{3}$ Group of Chemistry and Physics of the Atmosphere, University of the Azores, Terra Chã, Portugal.
}

Copyright 2006 by the American Geophysical Union. 0148-0227/06/2006JD007530\$09.00
2000], intercontinental [Forster et al., 2001; Honrath et al., 2004], and even hemispheric [Damoah et al., 2004] distances. It is recognized that boreal wildfires play an important role in the magnitude and interannual variability of tropospheric background $\mathrm{CO}$ in the Northern Hemisphere [e.g., Novelli et al., 2003; Edwards et al., 2004; Kasischke et al., 2005]. Recent studies have also shown increased mean background summertime $\mathrm{O}_{3}$ over northwestern North America [Jaffe et al., 2004], the central North Atlantic [Lapina et al., 2006] and Europe [Simmonds et al., 2005] associated with fire emissions transport. This indicates that boreal wildfires may also impact background $\mathrm{O}_{3}$.

[3] Ozone plays an important role in the chemistry of the atmosphere since it is estimated to be the third most important greenhouse gas [Houghton et al., 2001], and is the primary source of tropospheric hydroxyl radical. In addition, $\mathrm{O}_{3}$ has negative impacts on ecosystems and human 
health. Typically, tropospheric $\mathrm{O}_{3}$ production in the Northern Hemisphere is driven by anthropogenic emissions. However, boreal wildfires are an important source of $\mathrm{CO}, \mathrm{NO}_{x}$ and nonmethane hydrocarbons (NMHC), resulting in the potential for significant formation of $\mathrm{O}_{3}$ during the boreal fire season. Large-scale impacts of boreal fire emissions on tropospheric $\mathrm{O}_{3}$ can occur as a result of dispersion of $\mathrm{O}_{3}$ formed in boreal wildfire plumes. Alternatively, impacts on $\mathrm{CO}, \mathrm{NO}_{x}$ and NMHCs in the remote atmosphere could also lead to impacts on the $\mathrm{O}_{3}$ budget over a large region.

[4] The magnitude of the resulting impact of boreal wildfire emissions on tropospheric ozone is not yet well quantified. Prior observations in boreal wildfire plumes indicate $\mathrm{O}_{3}$ enhancements that range from very low in fresh plumes [e.g., Goode et al., 2000; Tanimoto et al., 2000] to low in moderately aged plumes [e.g., Wofsy et al., 1992; Mauzerall et al., 1996] to high in well-aged plumes [e.g., Honrath et al., 2004; Bertschi and Jaffe, 2005]. Boreal wildfire emissions have a large degree of variability, and are a function of fuel type (e.g., peat fires versus crown fires) and/or burning conditions (e.g., smoldering versus flaming) [Goode et al., 2000; Kasischke et al., 2005]. This causes uncertainty and variability in the emissions of $\mathrm{NO}_{x}$, a critical compound that controls $\mathrm{O}_{3}$ production rate.

[5] Measurements of a number of reactive nitrogen species over the North American boreal region were made during the ABLE3A and ABLE3B campaigns. These studies showed that the reactive nitrogen distribution over this region was significantly affected by boreal wildfire emissions [e.g., Sandholm et al., 1992; Singh et al., 1994]. However, the photochemical $\mathrm{O}_{3}$ production resulting from boreal wildfire $\mathrm{NO}_{x}$ emissions was concluded to be a negligible source of $\mathrm{O}_{3}$ over this region [Jacob et al., 1992; Mauzerall et al., 1996], because of a combination of low $\mathrm{NO}_{x}$ emissions and low estimated total fire magnitude. However, these studies suggested that dispersion of PAN produced in the fire plumes may provide a major source of $\mathrm{NO}_{x}$, particularly in warmer layers of the troposphere at low altitude [Jacob et al., 1992; Singh et al., 1994], and hence could contribute to $\mathrm{O}_{3}$ production far downwind from the fires. Consistent with this expectation, DeBell et al. [2004] reported significant enhancements of $\mathrm{NO}_{y}$ and $\mathrm{O}_{3}$ at several surface sites over the eastern United States resulting from a Quebec boreal wildfire plume in July 2002. However, most of these measurements were made in the boundary layer, and loss of $\mathrm{NO}_{y}$ and $\mathrm{O}_{3}$ by surface deposition may have obscured the true magnitude of the fire plume aloft.

[6] In addition to trace gases, boreal wildfires emit large amounts of aerosol black carbon (BC), on average about $10 \%$ of the annual anthropogenic BC emissions in the Northern Hemisphere [Bond et al., 2004]. Recently, it has been shown that $\mathrm{BC}$ emissions from boreal wildfires and anthropogenic sources can be efficiently transported to remote regions, such as the Arctic [Stohl et al., 2006] and the northwestern Pacific region [Park et al., 2005]. BC emissions are a significant factor in climate change because of their absorption of light in the atmosphere [Hansen et al., 2000; Bond and Sun, 2005]. Therefore the export of $\mathrm{BC}$ far downwind from the source emissions may contribute to the radiative forcing of the atmosphere, and thereby affect climate.

[7] During summer 2004, extensive wildfires burned in Alaska (the largest area on record) and western Canada, releasing large amounts of trace gases and aerosols into the atmosphere. For instance, $\mathrm{CO}$ emitted from mid-June to August was on the order of the anthropogenic CO emissions for the entire continental United States during that same time period [Pfister et al., 2005; S. Turquety et al., Inventory of boreal fire emissions for North America in 2004: The importance of peat burning and pyroconvective injection, submitted to Journal of Geophysical Research, 2006, hereinafter referred to as Turquety et al., submitted manuscript, 2006]. Intense plumes of these boreal wildfires were observed over large regions of North America and Europe by research aircraft [Flocke et al., 2005; de Gouw et al., 2006; E. Real et al., Processes influencing ozone levels in Alaskan forest fires plumes during long-range transport over the North Atlantic, submitted to Journal of Geophysical Research, 2006, hereinafter referred to as Real et al., submitted manuscript, 2006] and at several sites over the Arctic [Stohl et al., 2006] during the International Consortium for Atmospheric Research on Transport and Transformation (ICARTT) study [Fehsenfeld et al., 2006].

[8] In this paper, we present measurements of the composition of highly aged plumes from these fires sampled in the North Atlantic lower free troposphere (FT), using measurements at the PICO-NARE station. Measurements of $\mathrm{CO}, \mathrm{BC}, \mathrm{NO}_{y}, \mathrm{NO}_{x}$ and $\mathrm{O}_{3}$ made from June to early September 2004 are analyzed to assess the impact of boreal wildfires on levels of aerosol $\mathrm{BC}$ and nitrogen oxides $\left(\mathrm{NO}_{x}\right.$ and $\mathrm{NO}_{y}$ ) over the central North Atlantic lower FT, to characterize the associated enhancements of $\mathrm{O}_{3}$ in highly aged plumes, and to determine the resulting implications of the North American boreal wildfires for the regional and hemispheric $\mathrm{NO}_{x}$ and $\mathrm{O}_{3}$ budgets.

\section{Experimental Methods}

\subsection{PICO-NARE Station}

[9] Observations of $\mathrm{CO}, \mathrm{BC}, \mathrm{NO}_{x}, \mathrm{NO}_{y}$ and $\mathrm{O}_{3}$ were made at the PICO-NARE observatory from June to September 2004. The PICO-NARE station is situated on the summit caldera of the inactive volcano Pico (altitude $2.2 \mathrm{~km}$ ) in the Azores Islands, Portugal $\left(38^{\circ} \mathrm{N}, 28^{\circ} \mathrm{W}\right)$. The Azores are frequently impacted by airflow from high latitudes, which can transport emissions from boreal wildfires in Canada, Alaska and Siberia, and bring them to the Azores 6 to 15 days later. The station is located in the lower FT since marine boundary layer heights in this region are typically less than $1 \mathrm{~km}$ during the summer. Upslope flow can transport air from lower altitudes to the mountaintop, including occasionally from the boundary layer. However, a detailed assessment of the impact of upslope flow to the station found that upslope flow affects the PICO-NARE station much less than it does many other mountain observatories, and on many summer days tropospheric air is sampled throughout the day [Kleissl et al., 2006]. From June to September 2004, less than $25 \%$ of the time presented the meteorological conditions necessary for an air mass from below the mountain to reach the summit, i.e., weak synoptic winds and strong insolation for buoyant driven lifting or strong synoptic winds for mechanically driven lifting. Periods potentially affected by upslope flow were identified as described by Kleissl et al. [2006] and removed from the analysis. None of the periods discussed 
in detail below contain data affected by upslope flow. Further details on the PICO-NARE station and the occurrence of upslope flow to the station are presented elsewhere [Honrath et al., 2004; Kleissl et al., 2006].

\subsection{Measurements}

\subsubsection{Nitrogen Oxides}

[10] $\mathrm{NO}, \mathrm{NO}_{2}$, and $\mathrm{NO}_{y}$ were determined by an automated $\mathrm{NO}_{x, y}$ system developed at Michigan Technological University. This $\mathrm{NO}_{x, y}$ system is an improved version of the instrument previously described by Peterson and Honrath [1999]. $\mathrm{NO}, \mathrm{NO}_{2}$, and $\mathrm{NO}_{y}$ were determined using established techniques: $\mathrm{NO}$ detection by $\mathrm{O}_{3}$ chemiluminescence [Ridley and Grahek, 1990], $\mathrm{NO}_{2}$ by conversion to $\mathrm{NO}$ via ultraviolet photodissociation [Kley and McFarland, 1980; Parrish et al., 1990], and $\mathrm{NO}_{y}$ by Au-catalyzed reduction to NO in the presence of CO [Bollinger et al., 1983; Fahey et $a l ., 1985]$. The $\mathrm{NO}_{x, y}$ system was operated on an automated cycle, which included twice daily NIST-traceable calibration with $\mathrm{NO}$ and $\mathrm{NO}_{2}$, regular measurements of $\mathrm{NO}$ and $\mathrm{NO}_{2}$ (twice per week) and $\mathrm{NO}_{y}$ (once per week) artifacts in zero air, and determination of the $\mathrm{NO}_{y}$ conversion efficiency in ambient air of two $\mathrm{NO}_{y}$ compounds (i-propyl nitrate and $\left.\mathrm{HNO}_{3}\right)$ and one non-NO , compound $\left(\mathrm{CH}_{3} \mathrm{CN}\right)$. Measurements were recorded as 30-s averages ( $\mathrm{NO}$ and $\mathrm{NO}_{2}$ ) and 20-s averages $\left(\mathrm{NO}_{y}\right)$ every $10 \mathrm{~min}$, and were further averaged to obtain the 30-min averages used in this work. Ambient $\mathrm{NO}_{2}$ was determined by subtracting the signal due to ambient $\mathrm{NO}$ from the $\mathrm{NO}_{2}$ instrument signal, and further multiplying this term by the $\mathrm{NO}_{2}$ sensitivity [Gao et al., 1994]. $\mathrm{NO}_{x}$ was calculated as the sum of the 30-s average measurements of $\mathrm{NO}$ and $\mathrm{NO}_{2}$ during a single measurement cycle.

[11] Total uncertainty of the $\mathrm{NO}, \mathrm{NO}_{2}$ and $\mathrm{NO}_{y}$ measurements at low mixing ratios resulted from measurement precision and uncertainty in the instrument artifact correction, while measurement accuracy was the primary source of uncertainty at higher levels. The precision of individual measurements was mainly attributable to counting noise, which resulted from photon counting statistics. Excluding periods with high ambient variability, the precision $(2-\sigma)$ of the 30 -min averages was less than 6 pptv (median 5 pptv) for $\mathrm{NO}$, less than 13 pptv (median 10 pptv) for $\mathrm{NO}_{2}$, less than 14 pptv (median 10 pptv) for $\mathrm{NO}_{x}$, and less than 9 pptv (median 6 pptv) for $\mathrm{NO}_{y}$. Potential bias resulting from uncertainty in the artifact correction was estimated to be less than 2 pptv for $\mathrm{NO}, 4$ pptv for $\mathrm{NO}_{2}, 4$ pptv for $\mathrm{NO}_{x}$ and 2 pptv for $\mathrm{NO}_{y}$. Measurement accuracy was estimated to be $4 \%$ on the basis of total uncertainty of the sample and calibration mass flow controllers and the NO standard calibration gas mixing ratio.

[12] Accuracy of the $\mathrm{NO}_{y}$ measurements also depends on the effective conversion of $\mathrm{NO}_{y}$ compounds and the lack of significant conversion of non- $\mathrm{NO}_{y}$ compounds [Fahey et al., 1985; Kliner et al., 1997; Kondo et al., 1997], in addition to the accurate determination of the resulting NO. On the basis of results from standard addition tests and regular calibrations, the observed $\mathrm{NO}_{y}$ included $92-100 \%$ of the actual $\mathrm{NO}_{2}$ level (typically 97-100\%), with similar values expected for PAN [Fahey et al., 1985], 70-100\% of the actual $\mathrm{HNO}_{3}$ level, and $80-100 \%$ of the actual i-propyl nitrate. Measurements of $\mathrm{NO}_{y}$ presented in this work were corrected for nonunity $\mathrm{NO}_{y}$ conversion by using the $\mathrm{NO}_{2}$ conversion efficiencies measured at the system. A maximum correction of $8 \%$ was applied, and mainly affected the $\mathrm{NO}_{y}$ observations made from mid-July to mid-August when a degraded $\mathrm{NO}_{y}$ converter lowered the $\mathrm{NO}_{2}$ conversion efficiency to $92-95 \%$. A manual wet cleaning procedure was implemented in mid-August, and the $\mathrm{NO}_{2}$ conversion efficiency was restored back to the expected value of $97-100 \%$. In addition to the incomplete conversion of the $\mathrm{NO}_{y}$ species, this type of $\mathrm{NO}_{y}$ converter may overestimate true $\mathrm{NO}_{y}$ levels [Fahey et al., 1985; Kliner et al., 1997]. However, that was not a problem during this study. Interference from reduced nitrogen species (such as $\mathrm{NH}_{4}, \mathrm{HCN}$, and $\mathrm{CH}_{3} \mathrm{CN}$ ) was found to be always less than $0.3 \%$ during regular (twice daily) testing using standard addition of $\mathrm{CH}_{3} \mathrm{CN}$, a potential $\mathrm{NO}_{y}$ interferant present in biomass-burning plumes [de Gouw et al., 2003]. This level of $\mathrm{CH}_{3} \mathrm{CN}$ conversion in our system did not significantly contribute to the observations of $\mathrm{NO}_{y}$ gathered during boreal wildfire plumes: using the maximum enhancement of $\mathrm{CH}_{3} \mathrm{CN}$ relative to $\mathrm{CO}$ (3.52 pptv $\mathrm{CH}_{3} \mathrm{CN} / \mathrm{ppbv} \mathrm{CO}$ ) in the boreal fire plumes intercepted by the NOAA WP-3 research aircraft during summer 2004 [de Gouw et al., 2006], we estimate that the maximum impact of $\mathrm{CH}_{3} \mathrm{CN}$ on the $\mathrm{NO}_{y} / \mathrm{CO}$ enhancement ratios presented below is $0.01 \mathrm{pptv} / \mathrm{ppbv} \mathrm{CO}$, less than $0.2 \%$ of the lowest $\mathrm{NO}_{y} / \mathrm{CO}$ enhancement ratio reported below.

[13] Observations of nitrogen oxides made during periods with near-calm winds and high ambient variability were also excluded from the analysis. This was done for two reasons. First, calm winds may lead to the removal of $\mathrm{HNO}_{3}$ by deposition on the mountain surface. Therefore observations of $\mathrm{NO}_{y}$ during these periods may not be representative of the actual upwind $\mathrm{NO}_{y}$ levels. Second, unexpected spikes in ambient $\mathrm{NO}_{x}$ and $\mathrm{NO}_{y}$ were sometimes observed during low-wind periods (usually wind speeds less than $3 \mathrm{~m} / \mathrm{s}$ ), suggesting that a local source may have perturbed the measurements. On the basis of analysis of air sampled directly at several volcano vents (with $\mathrm{NO}_{x}$ reaching 1 to 8 ppbv), we deduce that volcanic emanations were the cause of the observed spikes. Therefore, to ensure that all the $\mathrm{NO}_{x}$ and $\mathrm{NO}_{y}$ observations were representative of free tropospheric air, we excluded (1) measurements made during low to calm winds (wind speed $<1 \mathrm{~m} / \mathrm{s}$ ), to avoid including $\mathrm{NO}_{y}$ observations with potential $\mathrm{HNO}_{3}$ removed on the mountain surface, and (2) measurements with high ambient variability, to avoid including nitrogen oxides resulting from volcanic emissions. For this purpose, periods with high ambient variability were defined as those when the 30-min $\mathrm{NO}_{x}$ standard error was above 10 pptv or the 30-min $\mathrm{NO}_{y}$ standard error exceeded $10 \mathrm{pptv}+0.25\left(\left[\mathrm{NO}_{y}\right]-90\right)$, where the second term was included to allow increased variability during periods of high $\mathrm{NO}_{y}$. The wind speed criterion removed $7 \%$ of the measurements during the study period, and the ambient variability screen removed an additional $23 \%$.

\subsection{2. $\mathrm{CO}$ and $\mathrm{O}_{3}$}

[14] CO was measured by a nondispersive infrared (NDIR) photometer (Thermo Environmental, Inc. (TEI), Model 48C-TL), modified as described by Parrish et al. [1994] and calibrated daily with a CO calibration gas referenced to the NOAA Global Monitoring Division 
standard. The instrument alternated between two minutes of zero measurement and two minutes of ambient measurement; the first minute of each mode was discarded to ensure equilibration. $\mathrm{O}_{3}$ was measured with a commercial ultraviolet absorption instrument (Thermo Environmental, Inc., Model 49C). The stability of the zero reading and the absence of $\mathrm{O}_{3}$ loss in the inlet and line were confirmed on a daily basis. $\mathrm{CO}$ and $\mathrm{O}_{3}$ data were recorded as one minute averages, and were further averaged to obtain the 30 minute averages used in this work. $\mathrm{CO}$ measurement uncertainty $(2-\sigma)$ was estimated to be $7 \%$ on the basis of total uncertainty of the sample and calibration mass flow controllers and the $\mathrm{CO}$ calibration standard mixing ratio. The 30 -min averages used in this work averaged seven to eight 1 -min average points, and had a precision $(2-\sigma)$ of 9 ppbv from June to mid-July, and 4 ppbv after mid-July. $\mathrm{O}_{3}$ measurement precision $(2-\sigma)$ was usually less than 1 ppbv, on the basis of the standard deviation of the thirty 1-min measurements included in each 30-min average. More details on the $\mathrm{CO}$ and $\mathrm{O}_{3}$ instruments are presented by Owen et al. [2006] and Honrath et al. [2004].

\subsubsection{Aerosol Black Carbon}

[15] Measurements of aerosol light absorption at seven wavelengths $(0.37,0.47,0.52,0.59,0.66,0.88$ and $0.95 \mu \mathrm{m})$ were conducted using an aethalometer (Magee Scientific, Model AE31). Briefly, this instrument determines the attenuation of light at these wavelengths transmitted through particles accumulated on a quartz filter, relative to a clean spot on the same filter. The change in attenuation as a function of time is used to determined the light absorption coefficient $\left(\sigma_{\text {aerosol }}\right)$. The $\sigma_{\text {aerosol }}$ as a function of wavelength is analyzed to identify the presence of non-BC absorbing compounds [Fialho et al., 2005] (none were significant during the period discussed here) and converted to equivalent $\mathrm{BC}$ using the calibration constant recommended by the manufacturer $\left(14.6 \mu \mathrm{m} \mathrm{m}^{2} \mathrm{~g}^{-1}\right)$. The equivalent $\mathrm{BC}$ values are referred to here as $\mathrm{BC}$. The detection limit of the aethalometer depends mainly on the stability of the optics, filter spot area errors, flow rate uncertainties and time error, and was estimated to be $25 \mathrm{ng} \mathrm{m}^{-3}(2-\sigma)$ for the integration period of one hour. More details on the aethalometer used in this study and the approach used to determine the $\mathrm{BC}$ concentrations are presented elsewhere [Fialho et al., 2005].

\subsection{Model Simulations and Transport Analysis}

[16] To identify periods apparently impacted by upwind boreal wildfire emissions, we examined $\mathrm{CO}$ mixing ratios simulated at the PICO-NARE station by the Model for OZone and Related Chemical Tracers (MOZART) global chemical transport model [Horowitz et al., 2003]. MOZART simulations were driven by 6-hourly meteorological fields from the National Centers for Environmental Predictions (NCEP) National Center for Atmospheric Research reanalysis. The spatial resolution of the model is $\sim 2.8^{\circ} \times 2.8^{\circ}$ with 28 levels between the surface to $2 \mathrm{hPa}$. The chemical time step of the model is 20 minutes. Emissions of CO from the 2004 North American boreal wildfires were optimized to match MOPITT CO observations using an inverse modeling technique [Pfister et al., 2005]. Boreal wildfire $\mathrm{CO}$ emissions were injected uniformly from 0 to $9 \mathrm{~km}$. MOZART simulations used in this work are mixing ratios averaged over 2-hour intervals and interpolated to the pressure and location of the PICO-NARE observatory [Pfister et al., 2006]. To assess the magnitude of fire impact at the PICO-NARE station, we used the MOZART-simulated ratio of $\mathrm{CO}$ fire tracer ( $\mathrm{CO}$ emitted from North American boreal wildfires) to total $\mathrm{CO}$ mixing ratio (i.e., $[\mathrm{CO}]_{\text {fire }}$ / $[\mathrm{CO}]_{\text {total }}$ ) interpolated to the measurement times (hereinafter termed the "MOZART fire-CO fraction").

[17] A second MOZART tracer was used for U.S. anthropogenic $\mathrm{CO}$ emissions to evaluate the contribution of anthropogenic emissions during the fire-impacted observations. For this purpose, we used the MOZART-simulated ratio of U.S. anthropogenic $\mathrm{CO}$ tracer to total $\mathrm{CO}$ mixing ratio at the PICO-NARE station (i.e., $[\mathrm{CO}]_{\text {anthro }} /[\mathrm{CO}]_{\text {total }}$ ) interpolated to the $30-\mathrm{min}$ average field observations (hereinafter termed the "MOZART anthro-CO fraction").

[18] To complement field observations and MOZART simulations, we used backward trajectories analysis. We calculated backward trajectories with the Hybrid SingleParticle Lagrangian Integrated Trajectories (HYSPLIT-4) model [Draxler and Rolph, 2003]. This model uses 6-hourly data from the NCEP global FNL meteorological data set. Ten-day backward trajectories were calculated every hour. At each hourly arrival time, six backward trajectories ending at six different locations near the PICO-NARE station were calculated: one centered at the station, four separated from the first by $1^{\circ}$ latitude and longitude, and one below the station, at $2000 \mathrm{~m}$.

\section{Results and Discussion}

[19] Time series of $\mathrm{CO}, \mathrm{BC}, \mathrm{NO}_{y}, \mathrm{NO}_{x}$ and $\mathrm{O}_{3}$ measurements and MOZART fire-CO fraction at the PICO-NARE station from July to 5 September 2004 are shown in Figure 1. Frequent periods with elevated $\mathrm{CO}$ levels coinciding with maxima of MOZART fire-CO fraction are evident.

\subsection{Identification of Fire-Impacted Periods}

[20] Periods when the hourly average of $\mathrm{CO}$ was above 110 ppbv and the MOZART fire-CO fraction was above 0.1 were identified as potentially impacted by upwind boreal wildfire emissions. The CO value of $110 \mathrm{ppbv}$ is well above typical background $\mathrm{CO}$ levels at the station and is approximately the maximum value observed in boreal region outflow in the absence of fires, as discussed in section 3.3.1 below. (Although we use 30-min averages of $\mathrm{CO}$ throughout the remainder of this work, for the purpose of identifying fire-impacted periods we used hourly averages of $\mathrm{CO}$ to smooth the $\mathrm{CO}$ measurements and compare them with the $\mathrm{CO}$ cutoff value.) The MOZART fire-CO fraction cutoff of 0.1 corresponds to approximately the 70th percentile of all model simulated values at the PICO-NARE station for summer 2004. Both of these cutoff values were designed to be conservative and, as a result, may omit some additional periods influenced by boreal wildfire emissions. For example, on 12 August 1200 UTC to 15 August 2300 UTC, an enhancement of MOZART fire-CO fraction above 0.1 was correlated with an increase in $\mathrm{CO}$, but $\mathrm{CO}$ did not exceed the 110 ppbv cutoff value. Conversely, on 30 July 0700-1100 UTC, the hourly average CO increased to 135 ppbv while backward trajectories indicated transport from active fires, but the MOZART fire-CO fraction was lower than 0.07 , likely as a result of the model spatial 

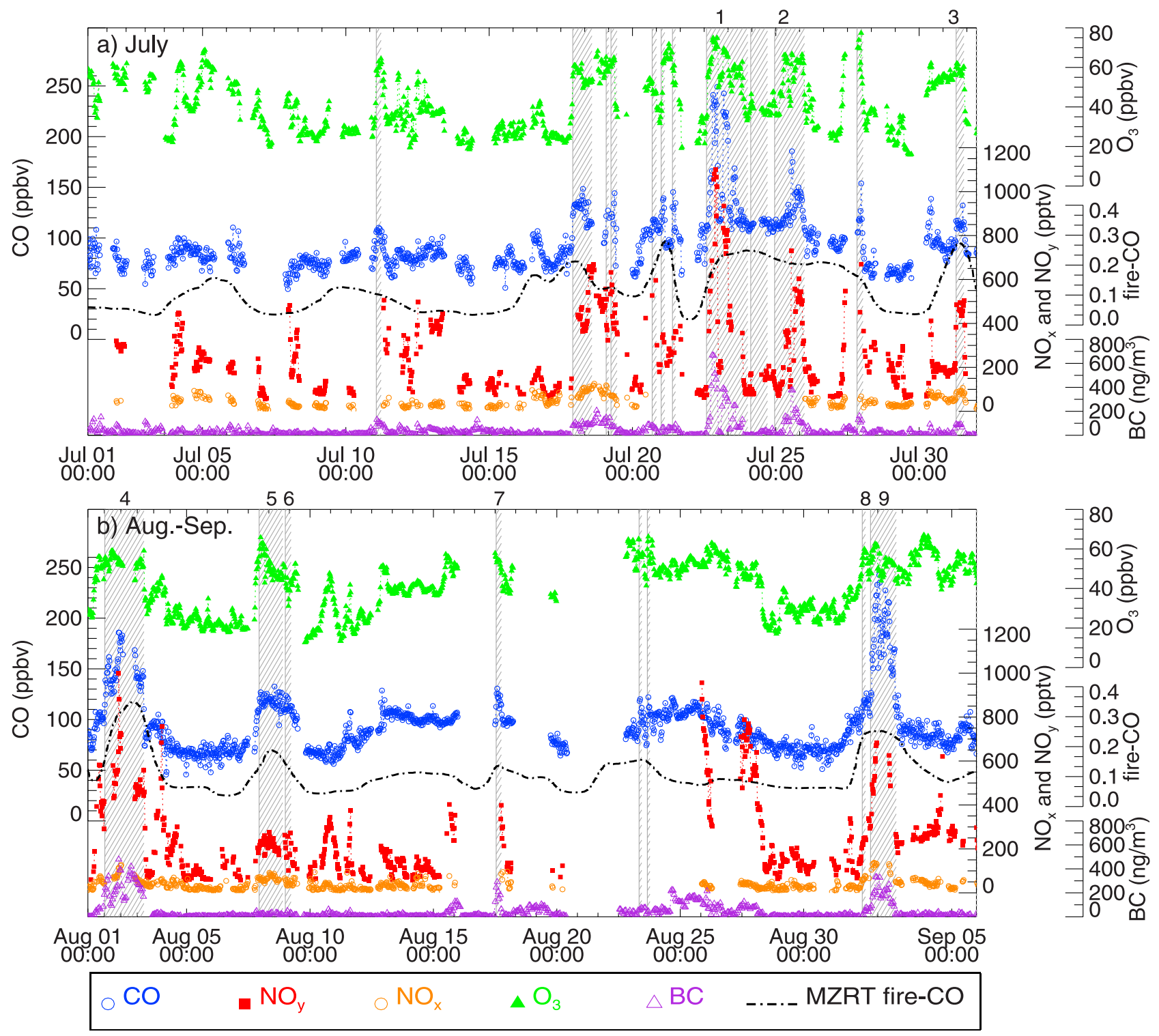

Figure 1. Summer 2004 time series of $\mathrm{CO}, \mathrm{BC}, \mathrm{NO}_{y}, \mathrm{NO}_{x}$ and $\mathrm{O}_{3}$ measurements and MOZART fire-CO fraction at the PICO-NARE station. $\mathrm{CO}$ is plotted with open blue circles, $\mathrm{NO}_{y}$ is plotted with red squares, $\mathrm{NO}_{x}$ is plotted with open orange circles, $\mathrm{BC}$ is plotted with open purple triangles, $\mathrm{O}_{3}$ is plotted with green triangles and MOZART fire-CO fraction is plotted with a dash-dotted line. Events identified as potentially boreal fire-impacted periods are identified with hatched areas; events further discussed in the text are numbered above the plot.

resolution. Although both of these cutoff values are somewhat arbitrarily selected, we find that the use of slightly larger or smaller cutoffs would not significantly affect the results presented below.

[21] In addition to outflow directly from the boreal regions, flow patterns that bring air to the Azores from higher latitudes can travel over the eastern United States [Owen et al., 2006]. Therefore transport of boreal wildfire emissions over the Azores may be mixed with air potentially containing North American anthropogenic emissions, which can also be characterized by significant enhancements of $\mathrm{CO}$ and $\mathrm{O}_{3}$ [Honrath et al., 2004]. To determine the magnitude of the impact of anthropogenic emissions during the boreal wildfire periods, we use the MOZART anthro-CO fraction (not shown in Figure 1). According to the MOZART simulations, anthropogenic emissions may explain some of the enhancements of $\mathrm{CO}$ at the station during summer 2004 either alone (e.g., 25 August, 08001900 UTC) or in combination with boreal wildfire emissions (e.g., 19 July, 0200-0900 UTC). To avoid inclusion of observations significantly affected by upwind anthropogenic emissions, we exclude from further analysis all observations with MOZART anthro-CO fraction values above 0.1 . This MOZART anthro-CO fraction cutoff corresponded to approximately the 70th percentile of all model values simulated at the site.

[22] To better understand transport patterns during the periods identified as fire-impacted, we examined backward trajectories arriving at the PICO-NARE station altitude. Consistent with MOZART simulations, backward trajecto- 
ries indicate transport of air that originated from the boreal regions in Alaska and/or Canada as shown in Figures $2 \mathrm{a}$ and $2 \mathrm{~b}$. However, the backward trajectories during a few periods indicated intermixing of subtropical and/or tropical air (hereinafter termed tropical air) with the boreal region outflow. Figure $2 \mathrm{~g}$ shows an example of tropical backward trajectories intermixed with boreal region outflow. Observations made during these periods may be affected by clean tropical air and, thus, may not be representative of boreal region outflow. We identified periods potentially affected by tropical air when one or more backward trajectories originated over the Atlantic Ocean south of Pico Island $\left(<35^{\circ} \mathrm{N}\right)$ and spent more than $90 \%$ of the time over the Atlantic Ocean before arriving at the site. We therefore omit all observations associated with tropical air intermixing from the analysis, with the following exception: during 23 July 0200-1800 UTC, although tropical air masses intermixed with boreal region outflow upwind the station, very large mixing ratios of $\mathrm{CO}$ recorded during most of the period ([CO] $>180 \mathrm{ppbv})$ indicate a lack of significant tropical air impact.

[23] Periods identified as potentially affected by boreal wildfire emissions on the basis of $\mathrm{CO}$ enhancements and MOZART fire-CO fraction criteria are identified with hatched areas in Figure 1; periods identified with the same criteria, but excluding periods of anthropogenic or tropical influence are also enumerated in Figure 1. Table 1 provides the statistics of the observations of $\mathrm{CO}, \mathrm{BC}, \mathrm{NO}_{y}, \mathrm{NO}_{x}$ and $\mathrm{O}_{3}$ for both criteria, i.e., all fire-impacted observations and those excluding anthropogenic or tropical influence.

\subsection{Overview of Summer 2004 Boreal Wildfire Observations}

[24] The impact of boreal wildfire emissions at the PICONARE station was very frequent during summer 2004, as shown in Figure 1. A total of 21 events with apparent fire impact were identified during the period of study, accounting for $16 \%$ of the measurement time from 1 July to 5 September. Of these, 9 were unaffected by potential tropical or anthropogenic impacts. We focus only on these fire-impacted periods without anthropogenic or tropical influence, and refer to these periods as boreal wildfire events in the remainder of this paper. These 9 events are numbered in Figure 1. During these events, $\mathrm{BC}, \mathrm{NO}_{y}, \mathrm{NO}_{x}$ and $\mathrm{O}_{3}$ levels were also elevated and significantly correlated with $\mathrm{CO}$ in most of the cases. MOZART CO fire tracer ages calculated during the ICARTT study (10 July to 8 August) indicated the impact of North American fire emissions emitted 6 to 15 days earlier during the events identified during this period (i.e., events $1-5$ ).

[25] Figures $3 \mathrm{a}$ and $3 \mathrm{~b}$ show the time series of 30-min average observations of $\mathrm{CO}, \mathrm{NO}_{y}, \mathrm{NO}_{x}$ and $\mathrm{O}_{3}$, and 1-hour average observations of BC during 22-24 July and 1-2 September. These events, labeled respectively event 1 and event 9 in Figure 1, represent two of the most intense fire emission episodes observed during the study. Levels of $\mathrm{CO}, \mathrm{BC}, \mathrm{NO}_{y}$ and $\mathrm{O}_{3}$ during 22-24 July were extremely enhanced for more than a day, peaking at 249 ppbv, $665 \mathrm{ng} \mathrm{m}^{-3}, 1100$ pptv and 75 ppbv, respectively. ( $\mathrm{NO}_{x}$ measurements were not available during this event.) This period had the highest level of $\mathrm{CO}$ yet recorded at the PICO-NARE station. Similarly, $\mathrm{CO}, \mathrm{BC}, \mathrm{NO}_{y}, \mathrm{NO}_{x}$ and $\mathrm{O}_{3}$ levels were also strongly elevated for more than a day during 1-2 September, with peaks of $243 \mathrm{ppbv}, 329 \mathrm{ng} \mathrm{m}^{-3}$, 685 pptv, 134 pptv and 62 ppbv, respectively. The MOZART fire-CO fraction was also particularly high during these two events, as shown in Figure 1.

[26] Analyses of backward trajectories during events 1 and 9 confirm that the enhancements of these species occurred when airflow from Alaska and/or Canada arrived at the station. Examples of backward trajectories associated with the passage of the boreal fire plumes for these events are shown in Figures $2 \mathrm{a}$ and $2 \mathrm{~b}$. For comparison, Figures $2 \mathrm{~g}$ and $2 \mathrm{~h}$ show the airflow before the passage of each boreal fire plume. An important feature of these events is that the levels of these species remained constantly high for more than 24 hours, suggesting the impact of two very large highly aged plumes.

\subsection{Impacts of Boreal Wildfire Emissions}

[27] In this section, we assess the impacts of boreal wildfire emissions by comparing enhancements of $\mathrm{CO}$, $\mathrm{BC}, \mathrm{NO}_{y}, \mathrm{NO}_{x}$ and $\mathrm{O}_{3}$ in fire-impacted boreal outflow to levels under similar conditions but in the absence of fires. First, however, we discuss the estimation of levels during periods of boreal outflow in the absence of fire emissions.

\subsubsection{Estimation of Levels in Absence of Fires}

[28] To estimate the background concentration at the PICO-NARE station in air from the fire source region, but in the absence of fire emissions, we identified two periods when boreal region outflow reached the station prior to the occurrence of the large fires: 7 June 0500-0900 UTC and 19 June 0800-1900 UTC. Early June was a period with low area burned over northern North America, and as a result, with low boreal wildfire emissions (Turquety et al., submitted manuscript, 2006). Therefore we expect that the contribution of boreal wildfire emissions to our site was small during these two periods. This is consistent with MOZART simulations, which indicate a maximum fire-CO fraction of 0.05 during these periods.

[29] Figure 3c shows the time series of 30-min average observations of $\mathrm{CO}$ and $\mathrm{O}_{3}$ and 1-hour average observations of $\mathrm{BC}$ during the longer of these events, 19 June 08001900 UTC. $\left(\mathrm{NO}_{x}\right.$ and $\mathrm{NO}_{y}$ measurements were not available at this time.) Examples of the backward trajectories associated with the passage of the air masses during and before this period are shown in Figures $2 \mathrm{c}$ and $2 \mathrm{i}$, respectively. Average levels of $\mathrm{CO}, \mathrm{BC}$ and $\mathrm{O}_{3}$ during this period are used as background levels of these species for comparison with fire-impacted periods below. In addition, the maximum level of CO during this event (111 ppbv) was the basis for the $110 \mathrm{ppbv}$ cutoff to select the boreal fire-impacted periods, as discussed in section 3.1. (The $\mathrm{CO}$ and $\mathrm{O}_{3}$ background values used in this work are somewhat larger than the levels in nonfire air presented for the same data set by Lapina et al. [2006], because that analysis included periods with a mixture of boreal and nonboreal air).

[30] MOZART simulations during the other nonfire boreal outflow period indicate that anthropogenic emissions may have contributed to these observations (i.e., the MOZART anthro-CO fraction was above 0.1). However, nitrogen oxides measurements in non-fire-impacted boreal outflow were available only during the 7 June event. (Few measurements were available in June 2004 because of testing of the 
07/22/2004 20:00
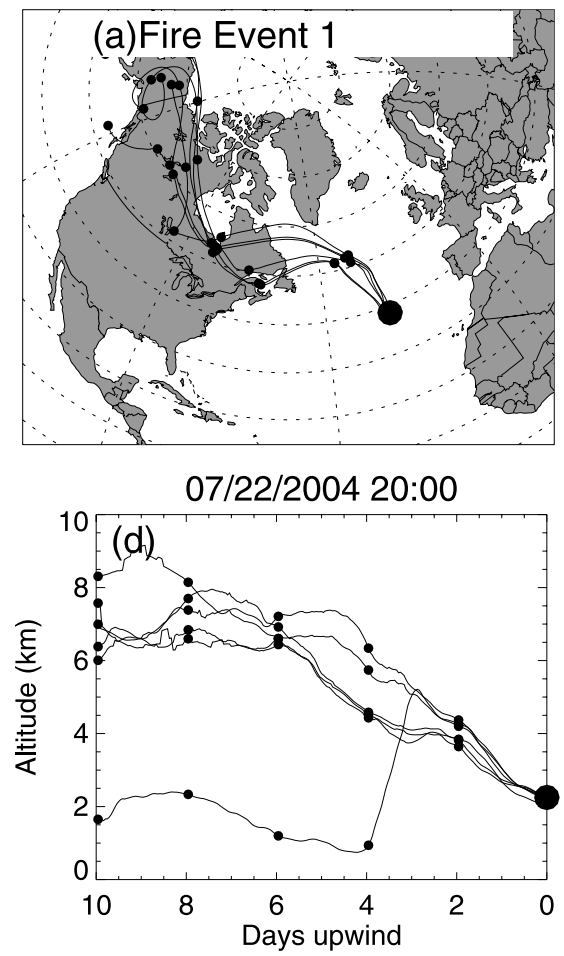

07/22/2004 15:00

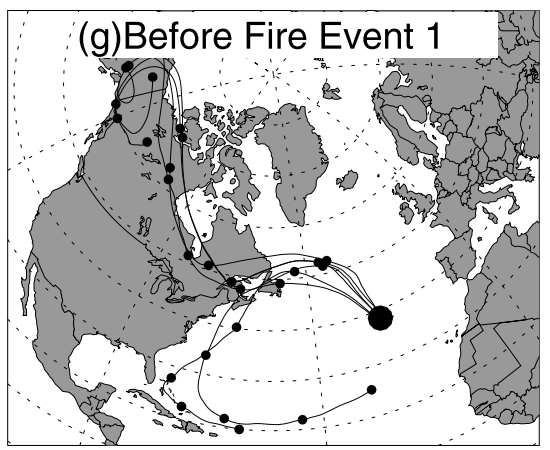

07/22/2004 15:00

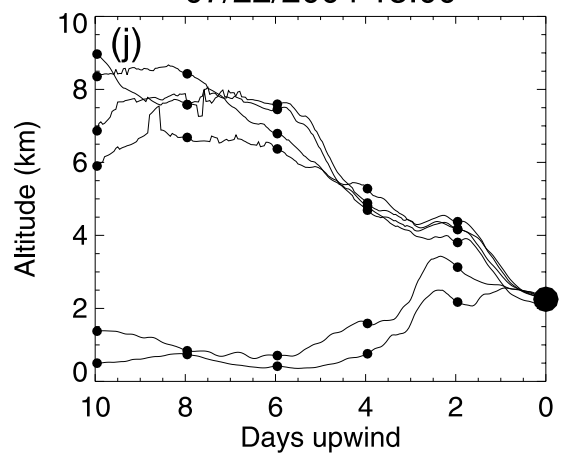

09/01/2004 21:00

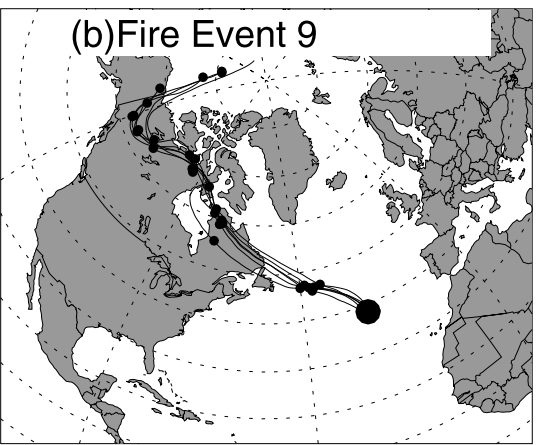

09/01/2004 21:00

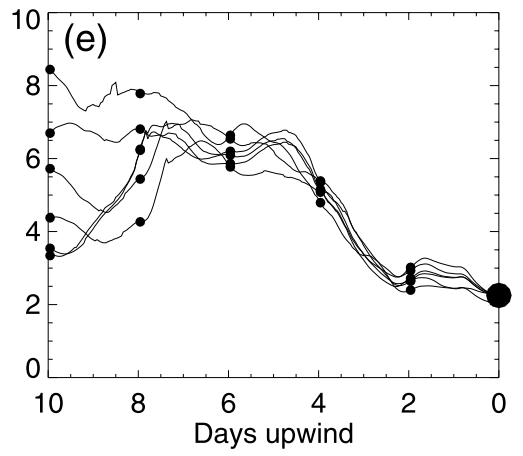

09/01/2004 02:00

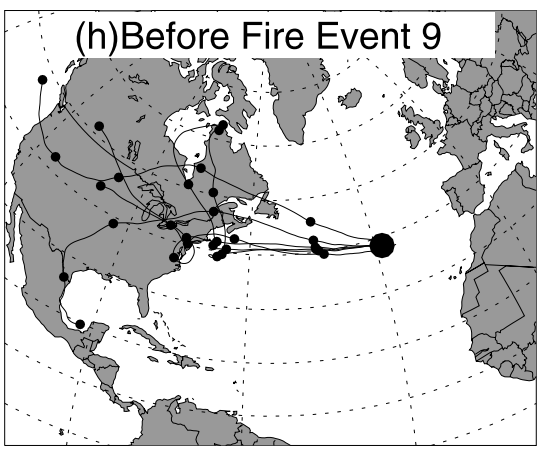

09/01/2004 02:00

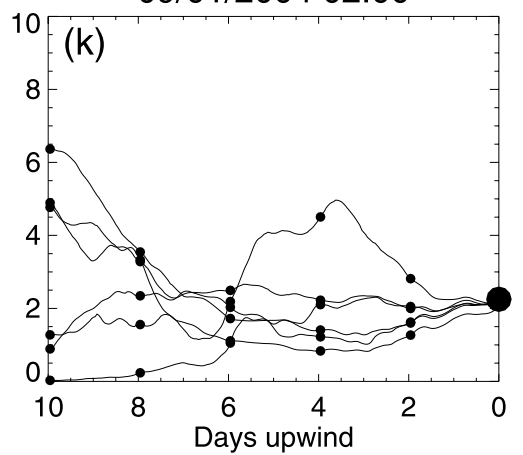

06/19/2004 13:00
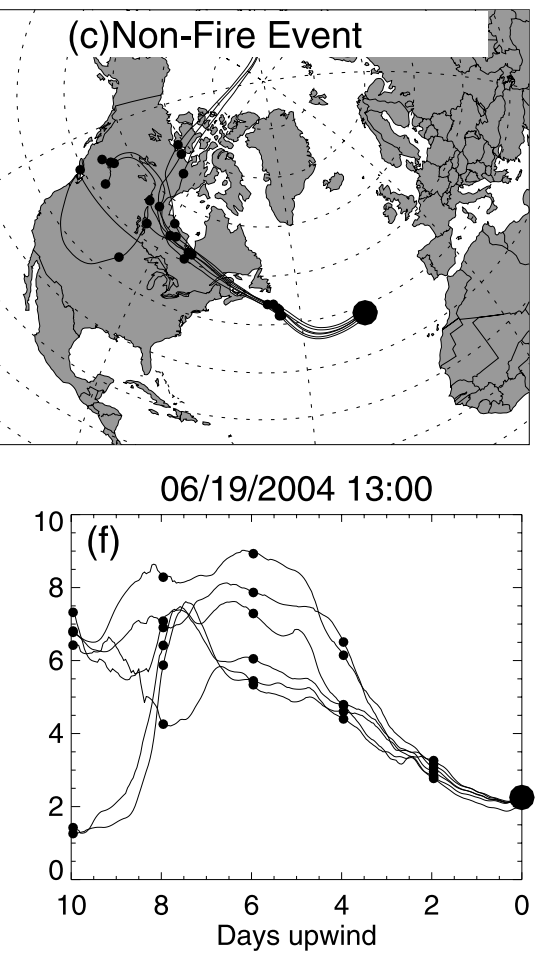

06/18/2004 22:00

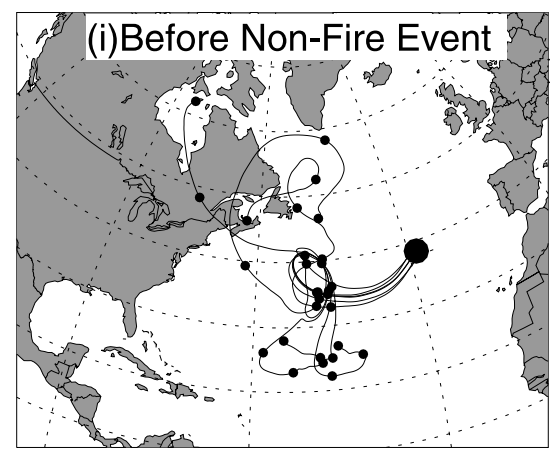

06/18/2004 22:00

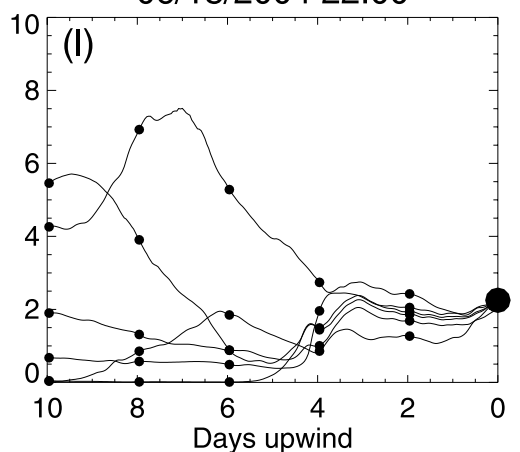

Figure 2. $(\mathrm{a}-\mathrm{c})$ Horizontal path of backward trajectories arriving at the measurement site during boreal region outflow for boreal region with upwind fire emissions (Figures $2 \mathrm{a}$ and $2 \mathrm{~b}$ ) and boreal region without upwind fire emissions (Figure 2c), along with $(\mathrm{d}-\mathrm{f})$ the altitude profile. $(\mathrm{g}-\mathrm{i})$ Horizontal path of backward trajectories before the passage of the boreal region air masses, along with $(j-1)$ the altitude profile. Solid lines show the paths of the six trajectories ending on a grid around and below the station; trajectory arrival times are displayed above each pair of plots. Small dots indicate each 2 days travel time. The location of the PICO-NARE station is marked with a large dot. 
Table 1. Comparison of $\mathrm{CO}, \mathrm{BC}, \mathrm{NO}_{y}, \mathrm{NO}_{x}$ and $\mathrm{O}_{3}$ Levels During the Boreal Fire Events With Observations During Periods of Flow From Boreal Region in Absence of Fires and With All Observations During Summer 2004 ${ }^{\mathrm{a}}$

\begin{tabular}{|c|c|c|c|c|c|c|c|c|c|c|}
\hline & \multicolumn{3}{|c|}{ Fire Observations ${ }^{\mathrm{b}}$} & \multicolumn{3}{|c|}{ Nonfire Observations ${ }^{\mathrm{c}}$} & \multicolumn{4}{|c|}{ Summer Observations ${ }^{\mathrm{d}}$} \\
\hline & Mean & Minimum-Maximum & $\mathrm{N}$ & Mean & Minimum-Maximum & $\mathrm{N}$ & Mean & Minimum-Maximum & Bckgrd $^{\mathrm{e}}$ & $\mathrm{N}$ \\
\hline $\mathrm{CO}, \mathrm{ppbv}$ & 139 & $107-249$ & 379 & 100 & $92-111$ & 23 & 93 & $46-249$ & 77 & 3254 \\
\hline w/o anthro, trop air & 144 & $108-249$ & 277 & & & & & & & \\
\hline $\mathrm{BC}^{\mathrm{f}} \mathrm{ng} \mathrm{m}^{-3}$ & 133 & $<25-665$ & 188 & 10 & $<25$ & 11 & 38 & $<25-665$ & 7 & 1705 \\
\hline w/o anthro, trop air & 153 & $<25-665$ & 133 & & & & & & & \\
\hline $\mathrm{NO}_{y}, \mathrm{pptv}$ & 389 & $71-1100$ & 238 & 139 & $127-148$ & 6 & 270 & $55-1380$ & 143 & 1625 \\
\hline w/o anthro, trop air & 406 & $71-1100$ & 178 & & & & & & & \\
\hline $\mathrm{NO}_{x}, \mathrm{pptv}$ & 77 & $33-137$ & 131 & 35 & $27-52$ & 6 & 38 & $1-137$ & 23 & 1525 \\
\hline w/o anthro, trop air & 77 & $33-137$ & 98 & & & & & & & \\
\hline $\mathrm{O}_{3}, \mathrm{ppbv}$ & 54 & $31-77$ & 379 & 46 & $42-52$ & 23 & 41 & $13-80$ & 30 & 3428 \\
\hline w/o anthro, trop air & 54 & $31-75$ & 277 & & & & & & & \\
\hline
\end{tabular}

${ }^{a}$ Reported are the average, minimum, maximum and number $(\mathrm{N})$ of 30-min averages for $\mathrm{CO}, \mathrm{NO}_{y}, \mathrm{NO}_{x}$ and $\mathrm{O}_{3}$, and 1-hour averages for $\mathrm{BC}$.

${ }^{\mathrm{b}}$ Fire-impacted observations from July to 5 September. First row shows all fire-impacted observations; second row (w/o anthro, trop air) shows fireimpacted observations without anthropogenic or tropical air impact (see text for explanation).

${ }^{\mathrm{c}} \mathrm{CO}, \mathrm{BC}$ and $\mathrm{O}_{3}$ observations are from 19 June; $\mathrm{NO}_{y}$ and $\mathrm{NO}_{x}$ observations are from 7 June (see text for explanation).

${ }^{\mathrm{d}}$ All observations from 1 June to 5 September 2004.

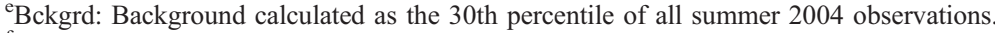

$f$ " $<$ " indicates BC values below detection limit.

instruments prior the ICARTT campaign.) Average mixing ratios of $\mathrm{NO}_{y}$ and $\mathrm{NO}_{x}$ during this period were used as upper limit estimates of the background of these species in boreal region outflow in the absence of fires.

[31] The background levels of $\mathrm{CO}, \mathrm{BC}, \mathrm{NO}_{y}, \mathrm{NO}_{x}$ and $\mathrm{O}_{3}$ used for boreal region outflow in the study are compared to background levels reported within the North American boreal region in Table 2. A wide range of background levels have been reported over the North American boreal region, reflecting differences in the latitude and altitude regions sampled, and the years of study. The values used here are similar to the background levels reported over the North American boreal region. The enhancement ratios calculated below are dependent on the background values used. This is discussed further in section 3.4.

\subsubsection{Comparison of Levels in Boreal Region Outflow With and Without Fire Emissions}

[32] Levels of $\mathrm{CO}, \mathrm{BC}, \mathrm{NO}_{y}, \mathrm{NO}_{x}$ and $\mathrm{O}_{3}$ during boreal region outflow with fire emissions are summarized and compared to levels observed during boreal region outflow without fire emissions in Table 1. Statistics for all summertime observations are also shown. Average $\mathrm{CO}$ mixing ratios during the boreal wildfire events $(144 \mathrm{ppbv})$ were above levels observed during flow from boreal region without fire emissions (100 ppbv), and were nearly double the summertime background (estimated as equal to the 30th percentile of all summertime measurements, $77 \mathrm{ppbv}$ ). This significant impact is consistent to what it has previously been observed at the PICO-NARE station [Honrath et al., 2004; Lapina et al., 2006], and for the entire Northern Hemisphere in years of high fire activity [e.g., Novelli et al., 2003; Edwards et al., 2004; Kasischke et al., 2005].

[33] Levels of $\mathrm{BC}, \mathrm{NO}_{y}, \mathrm{NO}_{x}$ and $\mathrm{O}_{3}$ were also increased during the fire-impacted events, with levels of these species above those observed in boreal outflow in the absence of fires, and well above the typical summertime background at the site. For example, average $\mathrm{NO}_{x}$ mixing ratios during the boreal wildfire events (77 pptv) were double those observed in boreal outflow without fire emissions ( $35 \mathrm{pptv}$ ) and triple the summertime background at the site ( $23 \mathrm{pptv})$.
[34] Figures $4 \mathrm{a}-4 \mathrm{~d}$ show the relationships between $\mathrm{CO}$ (used as a tracer of fire emissions) and $\mathrm{BC}, \mathrm{NO}_{y}, \mathrm{NO}_{x}$ and $\mathrm{O}_{3}$. Solid color-coded symbols represent observations obtained during each boreal wildfire event, with one exception: grey circles represent the early June observations made in nonfire boreal outflow discussed in section 3.3.1. Most of the fire-impacted observations were above the background from the boreal regions in the absence of fires, consistent with the average difference noted above. In almost all events, these species were well correlated with $\mathrm{CO}$, although distinct behaviors were observed depending on the levels of $\mathrm{CO}$, in particular for $\mathrm{O}_{3}$, as discussed further below.

[35] As discussed in section 3.1, a number of fire-impacted observations were excluded from the boreal wildfire events because of probable mixing of tropical air or MOZARTsimulated anthropogenic emission transport. These observations are also shown in Figure 4: observations omitted because of tropical air mixing are represented with open cyan circles and those omitted because of anthropogenic emissions impact are represented with open black squares. Observations omitted because of tropical air mixing fall into two distinct groups of points, suggesting differing degrees of mixing. Of the observations excluded because of anthropogenic impact, some had exceptionally large $\mathrm{NO}_{y}, \mathrm{NO}_{x}$ and $\mathrm{O}_{3}$ levels, suggesting significant anthropogenic impacts on those species as well. This impact is expect to be small in the events that were not excluded however. During those boreal wildfire events, MOZART-simulated anthropogenic CO was always below $7 \mathrm{ppbv}$, and usually $(60 \%$ of the observations) below 3 ppbv.

\subsection{Analysis of Enhancement Ratios in the Boreal Wildfire Plumes}

[36] To characterize the amount of emitted $\mathrm{BC}$ and $\mathrm{NO}_{x}$ that still remains in the plumes and the net $\mathrm{O}_{3}$ production occurring in these plumes during transport to the station, we determined the enhancement ratio of $\mathrm{BC}, \mathrm{NO}_{y}, \mathrm{NO}_{x}$ and $\mathrm{O}_{3}$ with respect to $\mathrm{CO}$ during each boreal wildfire event [e.g., Wofsy et al., 1992; Stohl et al., 2002]. CO is commonly used as a tracer because it is emitted from combustion processes 

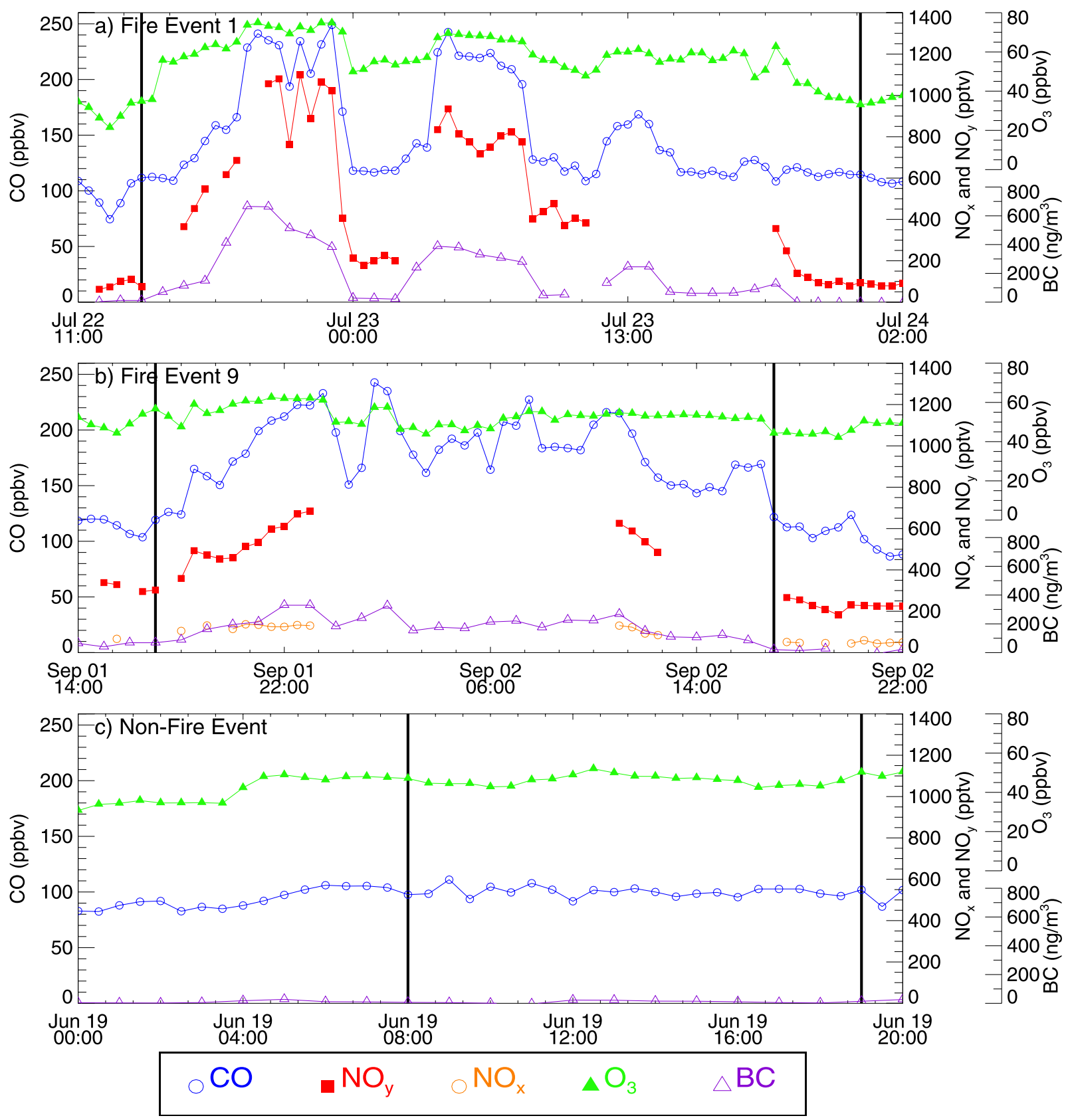

Figure 3. Time series of 30-min average $\mathrm{CO}, \mathrm{NO}_{x}, \mathrm{NO}_{y}$ and $\mathrm{O}_{3}$, and 1-hour average $\mathrm{BC}$ observations during two boreal wildfire events and one boreal outflow period without upwind fire emissions: (a) fire event 1, 22 July 1800 UTC to 23 July 2100 UTC $\left(\mathrm{NO}_{x}\right.$ measurements are not available); (b) fire event 9, 1 September 1630 UTC to 2 September 1600 UTC; and (c) nonfire event, 19 June 0800-1900 UTC $\left(\mathrm{NO}_{x}\right.$ and $\mathrm{NO}_{y}$ measurements are not available). $\mathrm{CO}$ is plotted with open blue circles, $\mathrm{NO}_{y}$ is plotted with red squares, $\mathrm{NO}_{x}$ is plotted with open orange circles, $\mathrm{BC}$ is plotted with open purple triangles and $\mathrm{O}_{3}$ is plotted with green triangles. Vertical solid lines indicate the start and end time of the event; remaining data are plotted to make the events more apparent.

in large quantities and has relatively a long lifetime [Novelli et al., 1992]. We consider CO as an inert tracer in this approach. de Gouw et al. [2006], on the basis of analysis of volatile organic compound (VOC) measurements, indicated that $\mathrm{OH}$ concentrations in the boreal wildfire plumes intercepted by the NOAA WP-3 were four times smaller than typical values in the North Atlantic troposphere. Hence CO reaction with $\mathrm{OH}$ is expected to be limited in the boreal fire plumes during the 6-15 days travel time to the station. We calculated mean values of $\Delta \mathrm{CO}, \Delta \mathrm{BC}, \Delta \mathrm{NO}_{y}, \Delta \mathrm{NO}_{x}$ and $\Delta \mathrm{O}_{3}$ during each boreal wildfire event, and calculated enhancement ratios relative to $\mathrm{CO}$ for each event using these mean values. Here $\Delta$ indicates the difference between the concentration of the indicated species and the background concentration (e.g., $\Delta \mathrm{CO}=[\mathrm{CO}]-[\mathrm{CO}]_{b k g d}$ ). Enhancement ratios are critically dependent on the background levels used 
Table 2. Estimated Background Levels Over the North American Boreal Region ${ }^{\mathrm{a}}$

\begin{tabular}{|c|c|c|c|c|c|c|c|c|}
\hline Study & Period & Location & Altitude, $\mathrm{km}$ & $\mathrm{CO}, \mathrm{ppbv}$ & $\mathrm{NO}_{y}, \mathrm{pptv}$ & $\mathrm{NO}_{x}, \mathrm{pptv}$ & $\mathrm{O}_{3}, \mathrm{ppbv}$ & $\mathrm{BC}, \mathrm{ng} \mathrm{m}^{-3}$ \\
\hline PICO-NARE ${ }^{b}$ & Jun 2004 & Pico, Azore & 2.2 & 100 & 139 & 35 & 46 & 10 \\
\hline ABLE3 $A^{c}$ & Jul-Aug 1988 & Sub- and Arctic & $<1-5.2$ & $91-100$ & $380-600$ & $19-24$ & $47-75^{\mathrm{d}}$ & n.r. \\
\hline $\mathrm{ABLE}^{\mathrm{e}} \mathrm{e}^{\mathrm{a}}$ & Jul-Aug 1990 & eastern Canada & $<1-6.2$ & $80-110$ & $164-542$ & $21-35$ & $25-65^{d}$ & n.r. \\
\hline Stohl06 ${ }^{\mathrm{f}}$ & Jun-Aug 2004-2005 & Summit, Greenland & 3 & n.r. & n.r. & n.r. & n.r. & 20 \\
\hline
\end{tabular}

an.r., not reported.

${ }^{b}$ Mean values during boreal region outflow in June, used for background levels in enhancement ratio calculations (see text for explanation).

${ }^{\mathrm{c}}$ Minimum and maximum values reported by Sandholm et al. [1992] and Jacob et al. [1992].

${ }^{\mathrm{d}}$ Large range of $\mathrm{O}_{3}$ reported reflects mainly $\mathrm{O}_{3}$ dependence on altitude.

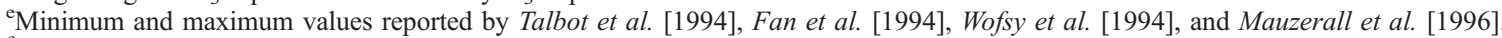

${ }^{\mathrm{f}}$ Median in summer 2004-2005 reported by Stohl el al. [2006].

[Mauzerall et al., 1998]. Our background levels were derived using observations during transport events in June, as discussed in section 3.3.1. This results in background levels higher than those that would be estimated using clean marine levels or using the 30th percentile of all summertime measurements. This leads to reduced calculated enhancement ratios for all the species.

[37] Table 3 presents the resulting enhancement ratios. A large variability of enhancement ratios was observed. There are two causes that probably contributed to the varying enhancement ratios: different emission rates, which vary as a function of fuel type and burning conditions [Goode et al., 2000; Reid et al., 2005], and varying degrees of removal during transport. We examine both processes in the following sections.

\subsubsection{Aerosol Black Carbon}

[38] The relationships between $\mathrm{BC}$ and $\mathrm{CO}$ in boreal fire plumes and in background air from boreal regions are shown in Figure $4 \mathrm{a}$. Estimated $\triangle \mathrm{BC} / \Delta \mathrm{CO}$ ratios for each boreal fire event are shown in Table 3. Black carbon was significantly enhanced in all events relative to background from boreal outflow without upwind fire emissions, with the exception of events 5 and 6 (green diamonds and black squares in Figure 4a, respectively).

[39] A broad range of $\mathrm{BC}$ enhancement ratios (0.5$8.4 \mathrm{ng} \mathrm{m}^{-3} / \mathrm{ppbv}$; Table 3) were observed in the boreal fire plumes. Large variability in $\mathrm{BC}$ emissions from boreal wildfires has been reported previously. For example, BC concentrations during smoldering combustion are low, with $\mathrm{BC}$ mass fractions typically $2-5 \%$ of all carbon particles emitted, while $\mathrm{BC}$ mass fractions from flaming combustion are 4 to $28 \%$ of all carbon particles emitted [Reid et al., 2005, and references therein].

[40] However, washout processes during transport to the station may also have contributed to this variability. To evaluate this possibility, we examined precipitation during transport and meteorological conditions at Pico during each event. For this purpose, we extracted rainfall rates from the HYSPLIT model output for the backward trajectories during each event and analyzed relative humidity measurements and archived photos of conditions at the station. Average rainfall rates were low (less than $0.05 \mathrm{~mm} / \mathrm{h}$ ) in all backward trajectories traveling from the boreal region to the station, with the exception of events 5,6 and 9, which showed average rainfall rates of $0.09,0.06$ and $0.08 \mathrm{~mm} / \mathrm{h}$, respectively. (These events are represented by green diamonds, black squares and blue diamonds in Figure 4a, respectively.) Conditions at the station were dry and sunny during all events, with the exception of event 6 , when heavy fog, and most likely rain, was present. Therefore the lower $\Delta \mathrm{BC} / \Delta \mathrm{CO}$ ratios during events 5, 6 and 9 compared to those during the other events are consistent with the wet scavenging of a greater fraction of $\mathrm{BC}$ during transport and/or at the station location during those events. This is consistent with previous observations of light absorbing aerosols (e.g., BC) in boreal fire plumes, which indicate that a large fraction of aerosols may be removed in the presence of rain and/or clouds [Bertschi and Jaffe, 2005; Stohl et al., 2006].

[41] The BC enhancement ratios we report are $8-141 \%$ (average $59 \%$, or $78 \%$ excluding events 5,6 and 9 ) of the $\mathrm{BC} / \mathrm{CO}$ emission ratio from extratropical forest fires $(6 \pm$ $\left.3 \mathrm{ng} \mathrm{m}^{-3} / \mathrm{ppbv}\right)$ recommended by Andreae and Merlet [2001]. (The value of $141 \%$ is not significantly different from $100 \%$, considering the uncertainties of the measurements and the recommended value.) These observations indicate that an important fraction of the total $\mathrm{BC}$ emitted into the plumes we sampled was efficiently exported to the Azores, very far downwind from the fires. This underscores other recent work that has documented long-range impacts of the North American wildfire BC emissions [Stohl et al., 2006; T. Duck et al., Transport of forest fire emissions from Alaska and the Yukon Territory to Nova Scotia during summer 2004, submitted to Journal of Geophysical Research, 2006]. Since BC effectively absorbs light in the atmosphere [Hansen et al., 2000; Bond and Sun, 2005], this implies a potentially significant large-scale impact of boreal wildfire emissions on the direct radiative forcing over the Northern Hemisphere troposphere.

\subsection{2. $\mathrm{NO}_{y}$}

[42] Figure $4 \mathrm{~b}$ shows the relationship between $\mathrm{NO}_{y}$ and $\mathrm{CO}$ in the boreal wildfire plumes and in background air from boreal regions without fire emissions. Table 3 provides the $\Delta \mathrm{NO}_{y} / \Delta \mathrm{CO}$ ratios estimated for each boreal fire event. Nitrogen oxides were significantly enhanced in all the boreal fire plumes, relative to background levels.

[43] The $\mathrm{NO}_{y}$ enhancement ratios were highly variable, however $(4.2-22.1 \mathrm{pptv} / \mathrm{ppbv}$; Table 3$)$. In the previous section, we concluded that the variation in $\mathrm{BC}$ enhancement ratios could be the result of a combination of emission variation among fires and wet removal during transit to the station. Since $\mathrm{NO}_{x}$ emissions also vary as a function of type of combustion [e.g., Yokelson et al., 1996; Goode et al., 2000] and a part of $\mathrm{NO}_{y}$ (i.e., $\mathrm{HNO}_{3}$ ) is susceptible to wet deposition, the same processes are expected to contribute to the variation of $\mathrm{NO}_{y}$ enhancement ratios. Consistent with this expectation, the events with the lowest $\Delta \mathrm{BC} / \Delta \mathrm{CO}$ ratios are also those with the lowest $\Delta \mathrm{NO}_{y} / \Delta \mathrm{CO}$ ratios (i.e., events 5,6 and 9). As a result, a plot of $\mathrm{NO}_{y}$ versus $\mathrm{BC}$ is 

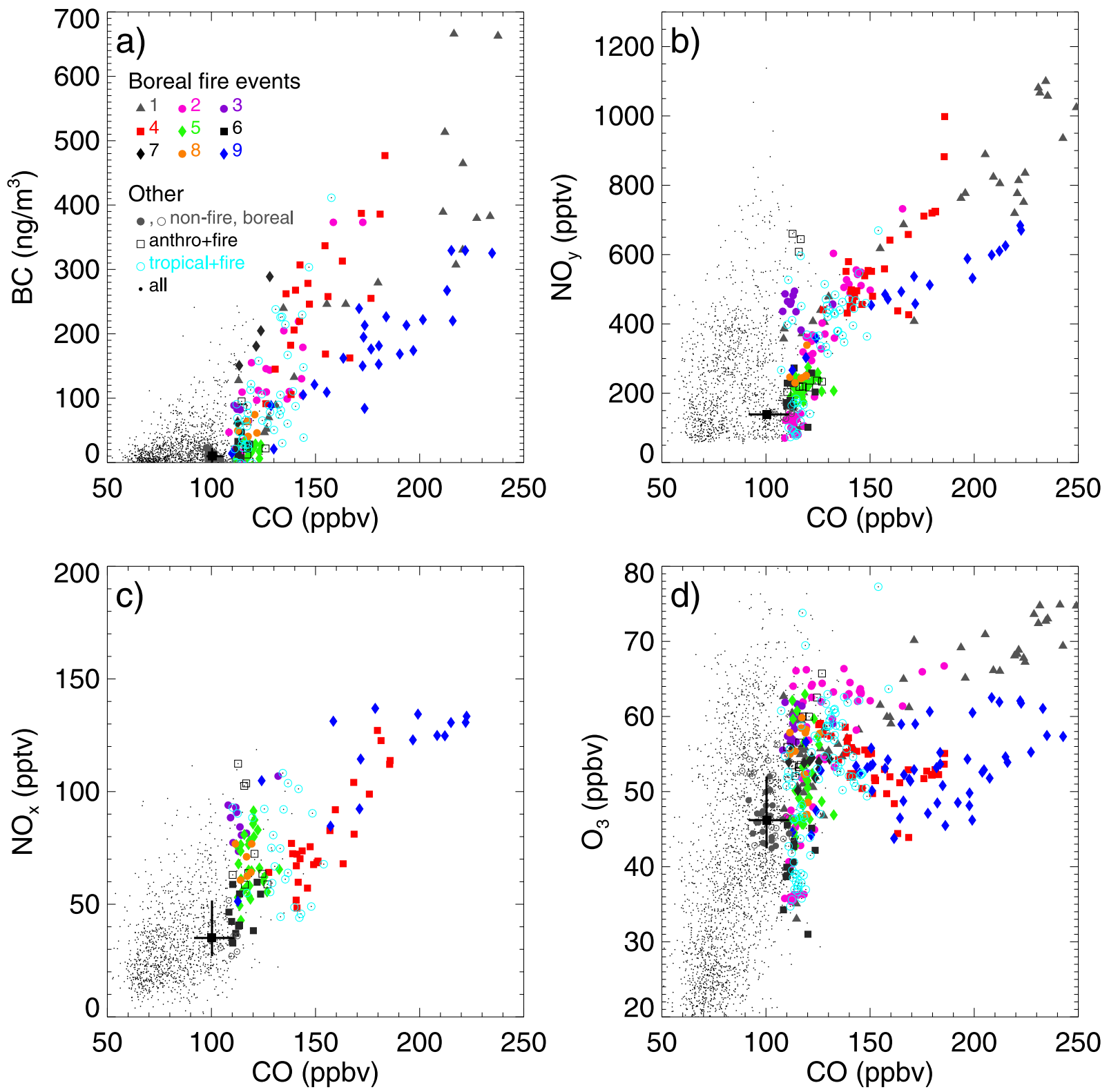

Figure 4. Relationship between $\mathrm{CO}$ and the indicated species during summer 2004: (a) $\mathrm{BC}$ versus $\mathrm{CO}$, (b) $\mathrm{NO}_{y}$ versus $\mathrm{CO}$, (c) $\mathrm{NO}_{x}$ versus $\mathrm{CO}$ and (d) $\mathrm{O}_{3}$ versus $\mathrm{CO}$. Boreal wildfire events listed in Table 3 and identified in Figure 1 are coded as follows: event 1 (dark grey triangles), event 2 (magenta circles), event 3 (purple circles), event 4 (red squares), event 5 (green diamonds), event 6 (black squares), event 7 (black diamonds), event 8 (orange circles) and event 9 (blue diamonds). Event 7 is not plotted for $\mathrm{NO}_{y}$ and $\mathrm{NO}_{x}$ because it contained fewer than 5 data points. Fire-impacted observations apparently impacted with tropical air are plotted with open cyan circles; fire-impacted observations apparently impacted with anthropogenic emissions are plotted with open black squares. Observations made during non-fire-impacted boreal outflow are plotted with small solid grey circles; non-fire-impacted boreal outflow observations with anthropogenic impact are plotted with open grey circles. The black square represents the average of non-fire-impacted boreal outflow observations, and black error bars connect minimum and maximum values observed. All other measurements during summer 2004 are plotted with small black dots.

less scattered than the plot of $\mathrm{NO}_{y}$ versus $\mathrm{CO}$, as shown in Figure 5, and the correlation of $\mathrm{NO}_{y}$ with $\mathrm{BC}\left(r^{2}=0.82\right)$ is slightly better than that with $\mathrm{CO}\left(r^{2}=0.75\right)$. Additional evidence for efficient $\mathrm{HNO}_{3}$ removal in some plumes is provided by aircraft measurements over the northwestern Atlantic Ocean, which found very low $\mathrm{HNO}_{3}$ to $\mathrm{NO}_{y}$ ratios in several 2004 North American fire plumes [Flocke et al., 2005].

[44] Table 4 compares these $\Delta \mathrm{NO}_{y} / \Delta \mathrm{CO}$ ratios to previous $\Delta \mathrm{NO}_{y} / \Delta \mathrm{CO}$ ratios obtained from previous studies of boreal wildfire plumes. The mean enhancement ratio we observed ( $8 \mathrm{pptv} / \mathrm{ppbv})$ is within the large range of mean 
Table 3. Enhancement Ratios of the Species During the Boreal Wildfire Events Identified in Figure $1^{\mathrm{a}}$

\begin{tabular}{|c|c|c|c|c|c|c|c|c|c|}
\hline \multirow[b]{2}{*}{ Event } & \multirow[b]{2}{*}{ Period } & \multicolumn{2}{|c|}{$\Delta \mathrm{BC} / \Delta \mathrm{CO}^{\mathrm{b}}$} & \multicolumn{2}{|c|}{$\Delta \mathrm{NO}_{y} / \Delta \mathrm{CO}^{\mathrm{b}}$} & \multicolumn{2}{|c|}{$\Delta \mathrm{NO}_{x} / \Delta \mathrm{CO}^{\mathrm{b}}$} & \multicolumn{2}{|c|}{$\Delta \mathrm{O}_{3} / \Delta \mathrm{CO}^{\mathrm{b}}$} \\
\hline & & $\mathrm{ng} \mathrm{m}^{-3} / \mathrm{ppbv}$ & $\mathrm{N}$ & $\mathrm{pptv} / \mathrm{ppbv}$ & $\mathrm{N}$ & $\mathrm{pptv} / \mathrm{ppbv}$ & $\mathrm{N}$ & $\mathrm{ppbv/ppbv}$ & $\mathrm{N}$ \\
\hline $1^{\mathrm{c}}$ & $22 \mathrm{Jul} 1800 \mathrm{UTC}$ to $24 \mathrm{Jul} 0000 \mathrm{UTC}$ & $3.60 \pm 0.84$ & 26 & $7.47 \pm 1.08$ & 35 & NA & NA & $0.23 \pm 0.03$ & 57 \\
\hline 2 & $24 \mathrm{Jul} 2300 \mathrm{UTC}$ to $25 \mathrm{Jul} 2330 \mathrm{UTC}$ & $3.72 \pm 0.87$ & 25 & 6.11 & 41 & NA & NA & $0.31=$ & 50 \\
\hline 3 & $31 \mathrm{Jul} 0700 \mathrm{UTC}$ to $31 \mathrm{Jul} 1300 \mathrm{UTC}$ & $4.91 \pm 0.48$ & 5 & $2.10 \pm 2.62$ & 10 & $3.63 \pm 0.46$ & 10 & $0.89 \pm 0.11$ & 13 \\
\hline 4 & 1 Aug 1930 UTC to 3 Aug 0130 UTC & $4.70 \pm 0.55$ & 20 & $8.10 \pm 0.62$ & 26 & $0.85 \pm 0.08$ & 25 & $0.14 \pm 0.01$ & 39 \\
\hline 5 & 8 Aug 0130 UTC to 8 Aug 1730 UTC & $0.47 \pm 0.17$ & 14 & $4.48 \pm 0.32$ & 29 & $1.73 \pm 0.14$ & 29 & $0.26 \pm 0.06$ & 33 \\
\hline 6 & 9 Aug 0000 UTC to 9 Aug 0530 UTC & $1.08 \pm 0.42$ & 6 & $4.17 \pm 1.17$ & 10 & $0.72 \pm 0.22$ & 12 & $-0.42 \pm 0.10$ & 12 \\
\hline 7 & 17 Aug 1300 UTC to 17 Aug 1730 UTC & $8.44 \pm 2.26$ & 5 & & & & & $0.37 \pm 0.04$ & 10 \\
\hline 8 & 1 Sep 1000 UTC to 1 Sep 1500 UTC & $2.50 \pm 0.41$ & 5 & $6.74 \pm 0.79$ & 7 & $1.92 \pm 0.18$ & 6 & $0.53 \pm 0.08$ & 11 \\
\hline 9 & 1 Sep 1700 UTC to 2 Sep 1730 UTC & $2.18 \pm 0.28$ & 25 & $4.67 \pm 0.34$ & 17 & $1.02 \pm 0.07$ & 14 & $0.09 \pm 0.01$ & 50 \\
\hline
\end{tabular}

${ }^{\mathrm{a}} \mathrm{NA}$, not available.

${ }^{\mathrm{b}}$ Reported enhancement ratios (calculated as described in text), 2- $\sigma$ uncertainty and number $(\mathrm{N})$ of simultaneous 30-min average observations of $\mathrm{NO}_{y}$, $\mathrm{NO}_{x}, \mathrm{O}_{3}$ and $\mathrm{CO}$, and simultaneous 1-hour average observations of $\mathrm{BC}$ and $\mathrm{CO}$. Events with $\mathrm{N}<5$ not shown.

${ }^{c}$ Event with apparent tropical air mixing impact.

values observed in plumes sampled over North America (5.6-14.1 pptv/ppbv; Table 4). The PICO-NARE mean enhancement ratio is also a significant fraction of the available (but poorly constrained) estimates of North American boreal fires $\mathrm{NO}_{x} / \mathrm{CO}$ emission ratios, e.g., $12 \mathrm{pptv} / \mathrm{ppbv}$ [Jain et al., 2006] or $26 \pm 15 \mathrm{pptv} / \mathrm{ppbv}$ [Andreae and Merlet, 2001]. These comparisons indicate that a significant fraction of the $\mathrm{NO}_{x}$ emitted into the sampled plumes was exported as $\mathrm{NO}_{y}$ to the lower FT over the Azores region.

[45] This conclusion contrasts with some prior studies of the export of anthropogenic $\mathrm{NO}_{y}$ to the FT, which conclude that a large majority of surface $\mathrm{NO}_{x}$ emissions $(>70 \%)$ is removed before or during export from the boundary layer during lofting mechanisms [e.g., Liang et al., 1998; Stohl et al., 2002; Parrish et al., 2004; Li et al., 2004].

[46] However, the boreal fire plumes sampled here differ from typical anthropogenic export in two key ways. First, in boreal wildfires PAN is expected to account for a significant fraction of $\mathrm{NO}_{y}$ [Jacob et al., 1992; Singh et al., 1994] as a result of lower $\mathrm{NO}_{x}$ /hydrocarbon emission ratios [Jacob et al., 1992]. Second, boreal wildfires can often be very energetic, releasing enough thermal energy to create smoke and convection columns that extend rapidly into the troposphere and even into the stratosphere [e.g., Fromm et al., 2005; Damoah et al., 2006]. The rapid vertical transport of emissions in fire-induced convection plumes soon after emission may contribute to the inefficient removal of $\mathrm{NO}_{y}$ during the lofting mechanism, as has been suggested for BC [Stohl et al., 2006]. In addition, as described above, most boreal fire plumes sampled at Pico were associated with low precipitation during transport as well as dry and sunny conditions at the site. Thus these conditions may have contributed to a more efficient export of $\mathrm{NO}_{y}$.

3.4.3. $\mathrm{NO}_{x}$

[47] Given the presumption of significant PAN content, the export of $\mathrm{NO}_{y}$ is expected to lead to $\mathrm{NO}_{x}$ release downwind from the fires. $\mathrm{NO}_{x}$ mixing ratios were indeed significantly enhanced in these plumes relative to background. Figure $4 \mathrm{c}$ shows the relationship between $\mathrm{NO}_{x}$ and $\mathrm{CO}$ in the boreal wildfire plumes and in background air from boreal regions in absence of fire emissions; $\Delta \mathrm{NO}_{x} / \Delta \mathrm{CO}$ ratios for the boreal wildfire events are listed in Table 3.

[48] The average of these $\mathrm{NO}_{x}$ enhancement ratios (1.6 pptv/ppbv; Table 4) is significantly larger than those reported previously in moderately aged boreal fire plumes (0.2-0.7 pptv/ppbv; Table 4 [e.g., Sandholm et al., 1992;
Mauzerall et al., 1996]). The occurrence of large enhancements of $\mathrm{NO}_{x}$ and large $\Delta \mathrm{NO}_{x} / \Delta \mathrm{CO}$ ratios in these plumes implies that decomposition of PAN to $\mathrm{NO}_{x}$, occurring as the plumes subside southward to the latitude of the Azores, may be an important source of $\mathrm{NO}_{x}$ to the lower troposphere. This is consistent with the large enhancements of $\mathrm{NO}_{y}$ observed at Pico as well as the large enhancements of $\mathrm{NO}_{y}$ and PAN detected in plumes at higher altitudes than Pico over eastern North America [Flocke et al., 2005] and over western Europe (H. Schlager, Deutsches Zentrum für Luft- und Raumfahrt (DLR), Germany, personal communication, 2006) during the ICARTT campaign.

[49] The overall impact of fire plumes on $\mathrm{NO}_{x}$ levels during summer 2004 was significant. Fire emissions were responsible for $36 \%$ of all observations of $\mathrm{NO}_{x}$ above $50 \mathrm{pptv}$ (and $90 \%$ of all observations above 100 pptv). Fire plumes also led to a significant impact on NO levels. The 9 boreal wildfire events were responsible for $29 \%$ of all observations

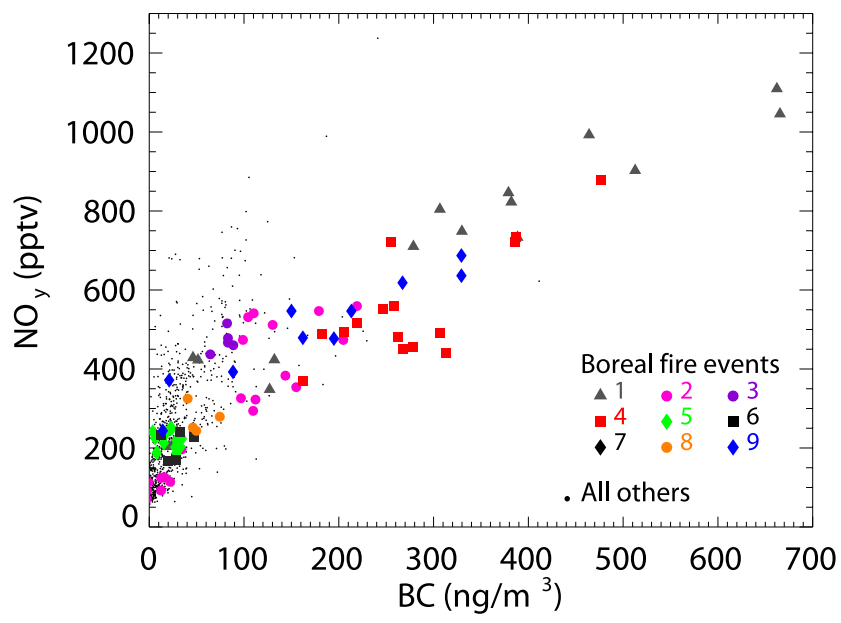

Figure 5. Relationship between $\mathrm{BC}$ and $\mathrm{NO}_{y}$ during summer 2004. Boreal wildfire events are coded as follows: event 1 (dark grey triangles), event 2 (magenta circles), event 3 (purple circles), event 4 (red squares), event 5 (green diamonds), event 6 (black squares), event 8 (orange circles) and event 9 (blue diamonds). Event 7 contained $<5$ simultaneous data points and is not plotted. All other measurements during summer 2004 are plotted with small black dots. 
Table 4. Enhancement Ratios of $\mathrm{NO}_{y}, \mathrm{NO}_{x}$ and $\mathrm{O}_{3}$ Relative to $\mathrm{CO}$ Observed in Boreal Fire Plumes ${ }^{\mathrm{a}}$

\begin{tabular}{|c|c|c|c|c|c|c|c|c|}
\hline Year & Fire Location & $\begin{array}{l}\text { Sampling } \\
\text { Location }\end{array}$ & $\begin{array}{c}\text { Plume Height, } \\
\text { km }\end{array}$ & $\begin{array}{c}\text { Travel Time, } \\
\text { day }\end{array}$ & $\begin{array}{c}\Delta \mathrm{NO}_{y} / \Delta \mathrm{CO},{ }^{\mathrm{b}} \\
\mathrm{pptv} / \mathrm{ppbv}\end{array}$ & $\begin{array}{c}\Delta \mathrm{NO}_{x} / \Delta \mathrm{CO},{ }^{b} \\
\mathrm{pptv} / \mathrm{ppbv}\end{array}$ & $\begin{array}{c}\Delta \mathrm{O}_{3} / \Delta \mathrm{CO},{ }^{\mathrm{b}} \\
\mathrm{ppbv} / \mathrm{ppbv}\end{array}$ & Source \\
\hline 2004 & AK, Can & Pico, Azores & 2.2 & $6-15$ & $8.0(4.2-22.1)$ & $1.6(0.7-3.6)$ & $0.2^{\mathrm{c}}(-0.4-0.9)$ & 1 \\
\hline 2002 & Quebec, Can & eastern U.S. & $0-2.5$ & $1-3$ & $4.1(2.4-7.4)$ & n.r. & $0.1(0.01-0.09)$ & 2 \\
\hline 1990 & Can, AK & eastern Can & $1-6.2$ & $<1$ & $14.1(2.5-37.8)$ & $0.7(0-3.8)$ & $0.2(0-0.7)$ & 3 \\
\hline 1988 & Sib, AK, Can & $\mathrm{AK}, \mathrm{Can}$ & $1.5-6.1$ & near fire & $10.9(5.7-15.2)$ & $0.2(0-0.52)$ & $0.35(0.1-0.7)$ & 4 \\
\hline 1988 & $\mathrm{AK}$ & $\mathrm{AK}$ & $2.0-4.5$ & $<1$ & $5.6(3.2-8.4)$ & n.r. & $0.095(0.014-0.18)$ & 5 \\
\hline 1997 & $\mathrm{AK}$ & interior $\mathrm{AK}$ & $1.6-1.8$ & $\sim 2$ hours & n.r. & n.r. & $0-0.09$ & 6 \\
\hline 1998 & eastern Sib & north Japan & $<1$ & $<1$ & n.r. & n.r. & 0.01 & 7 \\
\hline 1995 & Can & south U.S. & $0-3.0$ & $2-4$ & n.r. & n.r. & $0.11-0.17$ & 8 \\
\hline 2004 & AK, Can & N Atl, W Eur & $5-8$ & $4-9$ & n.r. & n.r. & $-0.01-0.08$ & 9 \\
\hline $2001-2003$ & Sib, AK, Can & Pico, Azores & 2.2 & $6-15$ & n.r. & n.r & $0.7(0.4-0.9)$ & 10 \\
\hline $2002-2003$ & $\mathrm{Sib}$ & NW U.S/NE Pacific & $0.7-5.0$ & $7-10$ & n.r. & n.r. & $0.4(0.2-0.8)$ & 11 \\
\hline
\end{tabular}

${ }^{a}$ n.r., not reported; Can, Canada; AK, Alaska; Sib, Siberia; N Atl, North Atlantic; W Eur, western Europe.

${ }^{\mathrm{b}}$ Reported average (minimum-maximum) in each measurement campaign (e.g., ABLE3B). Enhancement ratios were calculated using levels reported in background and biomass burning impacted air masses [e.g., Sandholm et al., 1992] or extracted directly from reported enhancement ratios [e.g., Wofsy et al., 1992]. References: 1, this work; 2, DeBell et al. [2004]; 3, ABLE3B [Talbot et al., 1994; Fan et al., 1994; Mauzerall et al., 1996]; 4, ABLE3A [Sandholm et al., 1992]; 5, ABLE3A [Wofsy et al., 1992]; 6, Goode et al. [2000]; 7, Tanimoto et al. [2000]; 8, SOS-95 [Wotawa and Trainer, 2000; McKeen et al., 2002]; 9, Real et al. (submitted manuscript, 2006); 10, PICO-NARE [Honrath et al., 2004]; and 11, Bertschi et al. [2004] and Bertschi and Jaffe [2005].

${ }^{c}$ Average of high-CO-enhancement events 1, 2, 4 and 9, as discussed in section 3.4.4.

of NO above $20 \mathrm{pptv}$, and the average daytime fire-impacted NO was significantly larger $(17 \pm 2$; mean $\pm 2-\sigma)$ than the average daytime NO for all summer observations $(11 \pm 1)$. The large $\mathrm{NO}$ and $\mathrm{NO}_{x}$ mixing ratios present in these wellaged boreal wildfire plumes indicate a significant impact on the regional $\mathrm{O}_{3}$ budget.

\subsubsection{Ozone}

[50] Figure 4d shows the relationship between $\mathrm{O}_{3}$ and $\mathrm{CO}$ in the boreal wildfire plumes and in background air from boreal regions without fire emissions. The estimated $\mathrm{O}_{3}$ enhancement ratio of each boreal fire event is provided in Table 3.

[51] The behaviors of $\mathrm{O}_{3}$ in the fire plumes varied from significant $\mathrm{O}_{3}$ enhancement in some plumes (e.g., event 1; grey triangles in Figure 4d) to $\mathrm{O}_{3}$ enhancement relative to background, with a negative $\mathrm{O}_{3}-\mathrm{CO}$ slope (e.g., event 4; red squares) to a smaller $\mathrm{O}_{3}$ enhancement (e.g., event 9; blue diamonds). Furthermore, several fire plumes presented relatively large $\Delta \mathrm{O}_{3} / \Delta C O$ ratios associated with only moderate $\mathrm{CO}$ enhancements (e.g., event 3; purple circles in Figure 4d; also events 5-8). The moderate CO enhancements during those periods make these events difficult to interpret, and therefore we focus here on the $\mathrm{O}_{3}$ enhancement ratios in the high-CO-enhancement events.

[52] The significant enhancements of $\mathrm{O}_{3}$ and large $\Delta \mathrm{O}_{3} /$ $\Delta \mathrm{CO}$ ratios (mean $0.2 \mathrm{ppbv} / \mathrm{ppbv}$ ) in these plumes are consistent with other studies that suggest that significant ozone production occurred downwind from boreal wildfires. For example, ozone enhancements of 20-30 ppbv were observed in boreal wildfire plumes after 5-7 days travel time to the southern United States [Wotawa and Trainer, 2000; Morris et al., 2006] and to Europe [Forster et al., 2001; Real et al., submitted manuscript, 2006]. Model simulations of the $\mathrm{O}_{3}$ formation in biomass burning plumes indicate that the slow recycling of PAN, and to a lesser extend $\mathrm{HNO}_{3}$ and organic nitrates, increases the effective lifetime of $\mathrm{NO}_{x}$ stimulating the continued formation of $\mathrm{O}_{3}$ in these plumes beyond the typical 1-day $\mathrm{NO}_{2}$ lifetime [Chatfield and Delany, 1990; Real et al., submitted manuscript, 2006].
[53] However, this mean $\Delta \mathrm{O}_{3} / \Delta \mathrm{CO}$ ratio is smaller than some reported previously and listed in Table 4 (e.g., 0.4$0.7 \mathrm{ppbv} / \mathrm{ppbv}$ [Honrath et al., 2004; Bertschi and Jaffe, 2005; Lapina et al., 2006]). This is mainly a result of the background value used here, as discussed in section 3.4. The average $\mathrm{O}_{3}$ enhancement ratio we calculate increases to $0.3 \mathrm{ppbv} / \mathrm{ppbv}$ if the 2004 summertime background (Table 1) is used. If, in addition, all boreal wildfire events are considered, i.e., moderate- and high-CO-enhancement events, the average $\Delta \mathrm{O}_{3} / \Delta \mathrm{CO}$ ratio increases to $0.5 \mathrm{ppbv} /$ ppbv (range $0.2-0.8 \mathrm{ppbv} / \mathrm{ppbv}$ ).

[54] The significant $\mathrm{O}_{3}$ enhancements observed during all but one event indicate $\mathrm{O}_{3}$ production in most of the sampled boreal wildfire plumes. However, although $\mathrm{O}_{3}$ levels were above background on average in all these events, the negative $\mathrm{O}_{3}-\mathrm{CO}$ slope observed in event 4 , and in parts of events 2 and 9 , and the very low $\Delta \mathrm{O}_{3} / \Delta \mathrm{CO}$ ratio in parts of event 9 imply the removal of $\mathrm{O}_{3}$ or the suppression of $\mathrm{O}_{3}$ production as well. This behavior is not fully understood, but may be due to one or a combination of the following causes.

[55] First, a reduction of the $\mathrm{O}_{3}$ production rates in the plumes would cause a low $\Delta \mathrm{O}_{3} / \Delta \mathrm{CO}$, but positive $\mathrm{O}_{3}-\mathrm{CO}$ slope. A flat relationship between $\mathrm{O}_{3}$ and $\mathrm{CO}$, in combination with large enhancements of PAN and little $\mathrm{NO}_{x}$ [Flocke et al., 2005] and large enhancements of VOCs [de Gouw et al., 2006], was observed in some of the boreal fire plumes intercepted by the NOAA W-P3 at higher altitudes than Pico. de Gouw et al. [2006], on the basis of VOC measurements, deduced that $\mathrm{OH}$ levels were depressed in these plumes. Similar conditions (i.e., large enhancements of PAN and VOCs) were observed at the BAe146 (Real et al., submitted manuscript, 2006). As a consequence of low $\mathrm{OH}$ concentrations and limited $\mathrm{NO}_{x}$ availability, $\mathrm{O}_{3}$ production rates may have been reduced. Similarly, Pfister et al. [2006] indicated that near the fire regions and, to a lesser extent downwind from the fires, $\mathrm{O}_{3}$ production may also be reduced because of the combination of a reduction in the production rate and an increase in the loss rate of back- 


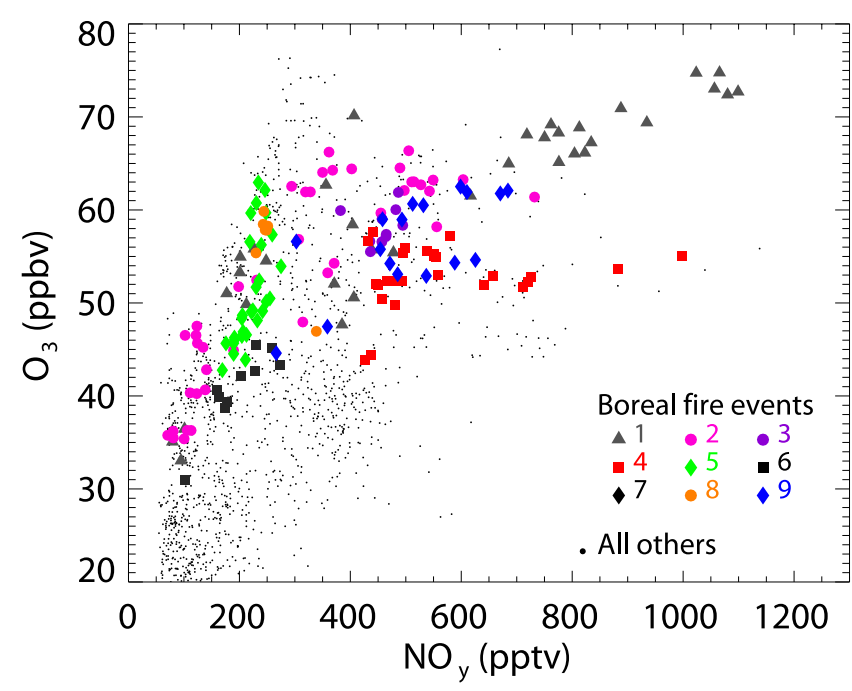

Figure 6. As Figure 5 but for the relationship between $\mathrm{O}_{3}$ and $\mathrm{NO}_{y}$.

ground $\mathrm{O}_{3}$, as a result of a decrease in $\mathrm{HO}_{x}\left(\mathrm{OH}+\mathrm{HO}_{2}\right)$ concentrations.

[56] Second, several studies have demonstrated the loss of $\mathrm{O}_{3}$ by reaction with organic compounds present in aerosols [e.g., de Gouw and Lovejoy, 1998; Griffin et al., 1999]. Biomass burning is a large source of smoke particles composed typically of organic carbon (OC) $\sim 50-60 \%$ and $\mathrm{BC} \sim 5-10 \%$ [Reid et al., 2005]. Given the significant levels of $\mathrm{BC}$ observed in the boreal fire plumes and the large ratio of $\mathrm{OC}$ to $\mathrm{BC}$ in biomass burning [Reid et al., 2005], $\mathrm{O}_{3}$ destruction on organic aerosols may have contributed to the reduced $\mathrm{O}_{3}$ enhancement ratio or the negative $\mathrm{O}_{3}-\mathrm{CO}$ relationship observed in some events.

[57] Finally, nighttime chemistry processes may also result in destruction of $\mathrm{O}_{3}$. At night, chemical processing of $\mathrm{NO}_{x}$ oxidizes $\mathrm{NO}_{x}$ to $\mathrm{HNO}_{3}$ via rapid heterogeneous hydrolysis of $\mathrm{N}_{2} \mathrm{O}_{5}$ in aerosols and initiates nocturnal oxidation of VOCs, with the concurrent destruction of $\mathrm{O}_{3}$ [Parrish et al., 1998; Brown et al., 2006]. Thus nocturnal $\mathrm{NO}_{x}$ emissions from boreal wildfires may result in a reduction of $\mathrm{O}_{3}$ and $\mathrm{NO}_{y}$, and result in reduced $\Delta \mathrm{O}_{3}$ / $\Delta \mathrm{CO}$ ratio or negative $\mathrm{O}_{3}-\mathrm{CO}$ relationships.

[58] To further investigate the photochemical properties of the plumes, we present the relationship between $\mathrm{O}_{3}$ and $\mathrm{NO}_{y}$ in Figure 6. With the exception of event $4, \mathrm{O}_{3}$ and $\mathrm{NO}_{y}$ showed positive correlations in all plumes $\left(r^{2}=0.5-0.8\right)$. Positive $\mathrm{O}_{3}-\mathrm{NO}_{y}$ correlations are consistent with our expectation of photochemical $\mathrm{O}_{3}$ production in the plumes, as a result of decomposition of PAN to $\mathrm{NO}_{x}$ occurring in the air masses during subsidence to the station. The sole exception, event 4 (red squares) exhibits no correlation between $\mathrm{O}_{3}$ and $\mathrm{NO}_{y}$ (Figure 6) and a negative $\mathrm{O}_{3}-\mathrm{CO}$ relationship (Figure $4 \mathrm{~d}$ ) and a larger $\mathrm{BC}-\mathrm{NO}_{y}$ relationship than the general trend (Figure 5). This situation suggests $\mathrm{O}_{3}$ destruction from organic aerosols during transport toward the station. However, the data available here are insufficient to test this hypothesis.

[59] Finally, we have evaluated the possibility that stratospheric $\mathrm{O}_{3}$ contributed to the $\mathrm{O}_{3}$ enhancements observed during some of these events. Stratospheric $\mathrm{O}_{3}$ frequently impacted the FT over eastern North America during summer 2004 (A. Thompson et al., IONS-04: New perspective on summertime UT/LS ozone over northeastern North America, submitted to Journal of Geophysical Research, 2006). Boreal fire plumes that impacted Pico were often associated with subsidence from altitudes of approximately $6-8 \mathrm{~km}$, suggesting a potential stratospheric impact. To assess this, we used FLEXPART stratospheric $\mathrm{O}_{3}$ tracer values simulated at the station location and altitude during 1 July to 16 August (A. Stohl, Norwegian Institute for Air Research (NILU), personal communication, 2006). Detailed information about the FLEXPART model is present elsewhere [Stohl et al., 2005]. This analysis indicated that stratospheric $\mathrm{O}_{3}$ occasionally impacted the station during the ICARTT period, but that the overall impact of stratospheric $\mathrm{O}_{3}$ was rather small: the average ( \pm standard deviation) of all stratospheric $\mathrm{O}_{3}$ tracer values was $8.4 \pm 5.2 \mathrm{ppbv}$. During the fire-impacted events, stratospheric $\mathrm{O}_{3}$ tracer values were usually reduced, rather than increased, with an average ( \pm standard deviation) of $5.8 \pm 4.2 \mathrm{ppbv}$. We found only one episode during the boreal fire events ( 7 August 2300 UTC to 8 August 2100 UTC) when the stratospheric $\mathrm{O}_{3}$ tracer was large (10 to $\left.18 \mathrm{ppbv}\right)$. This episode occurred during event 5 (green diamonds in Figure 4d). Even during this episode, the $\mathrm{O}_{3}$ enhancement during the event did not appear to be due to stratospheric $\mathrm{O}_{3}$, as FLEXPART stratospheric $\mathrm{O}_{3}$ tracer values did not increase relative to values before or after the event. Therefore we conclude that stratospheric $\mathrm{O}_{3}$ was not the cause of the enhancements of $\mathrm{O}_{3}$ observed during event 5 , and that the overall impact of stratospheric $\mathrm{O}_{3}$ was not significant during the boreal fire plumes analyzed in the study.

\subsection{Implications of Boreal Wildfires for the $\mathrm{NO}_{x}$ and $\mathrm{O}_{3}$ Budgets}

[60] The $\mathrm{NO}_{y}$ enhancement ratios observed at Pico may be used to estimate the total amount of $\mathrm{NO}_{x}$ emitted from the fires and exported in the plumes by multiplying the observed $\mathrm{NO}_{y} / \mathrm{CO}$ enhancement ratio by the fire $\mathrm{CO}$ emissions [Stohl et al., 2002; Parrish et al., 2004]. Pfister et al. [2005] estimated that $30 \pm 5 \mathrm{Tg}$ CO were emitted over the North American boreal region from mid-June to August, 2004, consistent with the estimate of Turquety et al. (submitted manuscript, 2006). Using the $\Delta \mathrm{NO}_{y} / \Delta \mathrm{CO}$ ratio at the PICO-NARE station (8.0 pptv/ppbv CO; Table 4) as an approximation of the impact of long-range-transported fire emissions, this $\mathrm{CO}$ emission implies that the fires contributed $0.12 \mathrm{Tg} \mathrm{NO}_{y}$ (as N). If, instead, we use total boreal fire $\mathrm{CO}$ emissions in a typical year $(\sim 61 \mathrm{Tg} \mathrm{CO}$; [Kasischke et al., 2005]), i.e., including Siberian emissions as well as North American, the total contribution to longrange-transported $\mathrm{NO}_{y}$ is estimated as $0.24 \mathrm{Tg}$. These values are quite large. For comparison, the amount of eastern North American $\mathrm{NO}_{x}$ emissions exported to the FT during midJune through August 2004 was approximately $0.30 \mathrm{Tg} \mathrm{NO}_{y}$ (as N). (This estimate is based on eastern U.S. $\mathrm{NO}_{x}$ emissions equal to two thirds of the U.S. national emissions during that period, using total $\mathrm{NO}_{x}$ U.S. emissions in 1999 reported by Parrish et al. [2004], adjusted for the $8.8 \%$ per year decrease of the on-road $\mathrm{CO}: \mathrm{NO}_{y}$ emission ratio, and estimated efficiency of export to the FT equal to approximately 25\% during summertime [e.g., Liang et al., 1998; 
Stohl et al., 2002; Parrish et al., 2004; Li et al., 2004].) These observations imply significant impacts of the boreal wildfires on the $\mathrm{NO}_{y}$ budget over downwind regions distant from the fires.

[61] If the $\mathrm{O}_{3}$ enhancement ratio at the PICO-NARE station applies to all fire emissions, the average $\Delta \mathrm{O}_{3} /$ $\Delta \mathrm{CO}$ ratio $(0.2 \mathrm{ppbv} / \mathrm{ppbv})$, combined with the total $\mathrm{CO}$ emitted from the North American wildfires (30 Tg) or with the typical $\mathrm{CO}$ emitted from boreal wildfires $(61 \mathrm{Tg})$, indicates that the boreal wildfires may have resulted in a source of $10-21 \mathrm{Tg}$ of $\mathrm{O}_{3}$ during summer 2004. This method is generally consistent with the MOZART analysis of fire-induced $\mathrm{O}_{3}$ production discussed by Pfister et al. [2006]. The monthly mean of our estimate $\left(4-8 \mathrm{Tg} \mathrm{O}_{3} /\right.$ month from mid-June to August) is $10-20 \%$ of the July net photochemical $\mathrm{O}_{3}$ production in the northern middle and high latitudes $\left(30-90^{\circ} \mathrm{N}\right.$; surface to $\left.350 \mathrm{hPa}\right)$ estimated by Emmons et al. [2003]. The ultimate impact could be even larger, since additional $\mathrm{O}_{3}$ is expected to form as a result of the $\mathrm{NO}_{x}$ and PAN still remaining in the transported plumes. Therefore our observations indicate that boreal wildfires may significantly impact the hemispheric $\mathrm{O}_{3}$ budget during the fire season.

[62] Given the current uncertainties in the $\mathrm{CO}$ emissions from boreal wildfires, the increase in dry and warm conditions over the boreal region [Hassol, 2004], and the increase in human-ignited fires [Mollicone et al., 2006], most likely the impact of boreal wildfires is significantly larger than previously believed.

\section{Conclusions}

[63] North American boreal wildfire emissions frequently impacted the PICO-NARE station during summer 2004. Using MOZART simulations and enhancements of $\mathrm{CO}$ levels, we identified 21 events of long-range transport of boreal wildfire emissions to the site, which accounted for $16 \%$ of the time from 1 July to 5 September 2004. Fireimpacted boreal region outflow resulted in extremely high levels of $\mathrm{CO}, \mathrm{BC}$ and nitrogen oxides, relative to other observations at the station, along with significant enhancements of $\mathrm{O}_{3}$. Analysis of $\mathrm{CO}, \mathrm{BC}, \mathrm{NO}_{y}, \mathrm{NO}_{x}$ and $\mathrm{O}_{3}$ observations during the boreal wildfire events showed that levels of all these species were above those in background air from similar outflow in the absence of fires, and well above typical summertime background levels at the site. This indicates a significant contribution from the North American wildfire emissions to background levels of these species over the North Atlantic region during summer 2004.

[64] Enhancement ratios relative to $\mathrm{CO}$ were somewhat variable, however. This is attributed to a combination of variation of fire types and emissions and removal during transport to the site. Analyses of $\triangle \mathrm{BC} / \Delta \mathrm{CO}$ and $\Delta \mathrm{NO}_{y} /$ $\Delta \mathrm{CO}$ indicated that a significant fraction of $\mathrm{BC}$ and $\mathrm{NO}_{y}$ resulting from the fires was scavenged in some plumes, but on average $\mathrm{BC}$ and $\mathrm{NO}_{y}$ were efficiently exported to the lower FT over the North Atlantic region. Analyses of $\Delta \mathrm{NO}_{x} / \Delta \mathrm{CO}$ ratios suggested that decomposition of PAN to $\mathrm{NO}_{x}$, occurring as the plumes subside southward to the Azores, was an important source of $\mathrm{NO}_{x}$. High levels of $\mathrm{NO}$ and $\mathrm{NO}_{x}$ imply continuing $\mathrm{O}_{3}$ formation in these highly aged plumes.
[65] Ozone levels were also significantly enhanced. Analysis of $\Delta \mathrm{O}_{3} / \Delta \mathrm{CO}$ ratios indicated a varying behavior from plume to plume, with significant to moderate $\mathrm{O}_{3}$ production, and included negative $\mathrm{O}_{3}-\mathrm{CO}$ slopes in some plumes. We discussed several mechanisms that may have contributed to the complex behavior of $\mathrm{O}_{3}$ in the fire plumes, and suggest that further work is needed to better understand this effect. However, the $\mathrm{O}_{3}$ enhancements present in all but one plume indicate that significant photochemical production occurred during transport, most likely as a result of decomposition of PAN to $\mathrm{NO}_{x}$. Lower $\mathrm{O}_{3}$ production in other plumes may have resulted from a reduction in the $\mathrm{O}_{3}$ production rates due to reduced $\mathrm{OH}$ concentrations and limited $\mathrm{NO}_{x}$, or from destruction of $\mathrm{O}_{3}$ during transport due to reaction with organic aerosols or nighttime chemistry.

[66] Our analyses demonstrate that boreal wildfire emissions can result in a significant source of $\mathrm{BC}, \mathrm{NO}_{x}$ and $\mathrm{O}_{3}$ in the central North Atlantic lower FT. Since our observations were made very far downwind from the fires, this suggests very large-scale impacts of boreal wildfires both on direct radiative forcing by $\mathrm{BC}$ and on tropospheric $\mathrm{NO}_{x}$ and $\mathrm{O}_{3}$ budgets. Recent studies have shown a positive trend in the amount of areas burned over recent decades [Gillett et al., 2004; Kasischke and Turetsky, 2006], likely as a result of warmer and drier conditions in the boreal region [Hassol, 2004], and possibly in combination with direct human impacts [Mollicone et al., 2006]. Global Circulation Models predict more frequent and more severe fires as the climate changes [Stocks et al., 1998; Flannigan et al., 2000]. Thus the impact of boreal wildfires may become even more important in the near future.

[67] Acknowledgments. We appreciate the efforts of many people involved in the development and installation of the PICO-NARE station, in particular Mike Dziobak for his continuous efforts in helping to maintain and run the station and Matt Peterson for the codevelopment of the $\mathrm{NO}_{x, y}$ system. In addition, we thank Jan Kleissl for providing the analysis of upslope flow periods, Jessica Strane for her assistance in airflow analyses, and Kateryna Lapina for her comments on boreal wildfire emission factors. We acknowledge Andreas Stohl for providing us with the FLEXPART stratospheric $\mathrm{O}_{3}$ tracer simulations and the NOAA Air Resources Laboratory for provision of the HYSPLIT transport model. This work was supported by NOAA, Office of Global Programs, grants NA16GP1658, NA86GP0325 and NA03OAR4310002; the National Science Foundation, grants ATM-0215843, ATM-0535486 and INT-0110397; and Fundação para a Ciência e Tecnologia (FTC-Portugal) project POCTI-32649-CTA2000 and grant SFRH/BD/9049/2002.

\section{References}

Andreae, M., and P. Merlet (2001), Emissions from trace gases and aerosols from biomass burning, Global Biogeochem. Cycles, 15, 955-966.

Bertschi, I. T., and D. A. Jaffe (2005), Long-range transport of ozone, carbon monoxide, and aerosols to the NE Pacific troposphere during the summer of 2003: Observations of smoke plumes from Asian boreal fires, J. Geophys. Res., 110, D05303, doi:10.1029/2004JD005135.

Bertschi, I. T., D. A. Jaffe, L. Jaegl, H. U. Price, and J. B. Dennison (2004), PHOBEA/ITCT 2002 airborne observations of transpacific transport of ozone, $\mathrm{CO}$, volatile organic compounds, and aerosols to the northeast Pacific: Impacts of Asian anthropogenic and Siberian boreal fire emissions, J. Geophys. Res., 109, D23S12, doi:10.1029/ 2003JD004328.

Bollinger, M. J., R. E. Sievers, D. W. Fahey, and F. C. Fehsenfeld (1983), Conversion of nitrogen dioxide, nitric acid, and n-propyl nitrate to nitric oxide by gold-catalyzed reduction with carbon monoxide, Anal. Chem., $55,1980-1986$

Bond, T. C., and H. Sun (2005), Can reducing black carbon emissions counteract global warming?, Environ. Sci. Technol., 39, 5921-5926, doi:10.1021/es0480421.

Bond, T. C., D. G. Streets, K. F. Yarber, S. M. Nelson, J.-H. Woo, and Z. Klimont (2004), A technology-based global inventory of black and 
organic carbon emissions from combustion, J. Geophys. Res., 109 D14203, doi:10.1029/2003JD003697.

Brown, S. S., et al. (2006), Variability in nocturnal nitrogen oxide processing and its role in regional air quality, Science, 311(5757), 67-70, doi: $10.1126 /$ science. 1120120 .

Chatfield, R. B., and A. C. Delany (1990), Convection links biomass burning to increased tropical ozone: However, models will tend to overpredict $\mathrm{O}_{3}$, J. Geophys. Res., 95, 18,473-18,488.

Damoah, R., N. Spichtinger, C. Forster, P. James, I. Mattis, U. Wandinger, S. Beirle, T. Wagner, and A. Stohl (2004), Around the world in 17 daysHemispheric-scale transport of forest fire smoke from Russia in May 2003, Atmos. Chem. Phys., 4, 1449-1471.

Damoah, R., et al. (2006), A case study of pyro-convection using transport model and remote sensing data, Atmos. Chem. Phys., 6, 173-185.

DeBell, L. J., R. W. Talbot, J. E. Dibb, J. W. Munger, E. V. Fischer, and S. E. Frolking (2004), A major regional air pollution event in the northeastern United States caused by extensive forest fires in Quebec, Canada, J. Geophys. Res., 109, D19305, doi:10.1029/2004JD004840.

de Gouw, J. A., and E. R. Lovejoy (1998), Reactive uptake of ozone by liquid organic compounds, Geophys. Res. Lett, 25(6), 931-934

de Gouw, J. A., C. Warneke, D. D. Parrish, J. S. Holloway, M. Trainer, and F. C. Fehsenfeld (2003), Emission sources and ocean uptake of acetonitrile $\left(\mathrm{CH}_{3} \mathrm{CN}\right)$ in the atmosphere, J. Geophys. Res., 108(D11), 4329 , doi:10.1029/2002JD002897.

de Gouw, J. A., et al. (2006), Volatile organic compounds composition of merged and aged forest fire plumes from Alaska and western Canada J. Geophys. Res., 111, D10303, doi:10.1029/2005JD006175.

Draxler, R., and G. Rolph (2003), HYSPLIT4 model (HYbrid SingleParticle Lagrangian Integrated Trajectory) model, NOAA Air Resour Lab., Silver Spring, Md. (Available at http://www.arl.noaa.gov/ready/ hysplit4.html)

Edwards, D. P., et al. (2004), Observations of carbon monoxide and aerosols from the Terra satellite: Northern Hemisphere variability, J. Geophys. Res., 109, D24202, doi:10.1029/2004JD004727.

Emmons, L. K., et al. (2003), Budget of tropospheric ozone during TOPSE from two chemical transport models, J. Geophys. Res., 108(D8), 8372 doi:10.1029/2002JD002665

Fahey, D. W., C. S. Eubank, G. Hubler, and F. C. Fehsenfeld (1985), Evaluation of a catalytic reduction technique for the measurement of total reactive odd-nitrogen $\mathrm{NO}_{y}$ in the atmosphere, J. Atmos. Chem., 3, 435468

Fan, S., et al. (1994), Origin of tropospheric $\mathrm{NO}_{x}$ over subarctic eastern Canada in summer, J. Geophys. Res, 99(D8), 16,867-16,878

Fehsenfeld, F., et al. (2006), International Consortium for Atmospheric Research on Transport and Transformation (ICARTT): North America to Europe: Overview of the 2004 summer field study, J. Geophys. Res., doi:10.1029/2006JD007829, in press.

Fialho, P., A. D. A. Hansen, and R. E. Honrath (2005), Absorption coefficients by aerosols in remote areas: A new approach to decouple dust and black carbon absorption coefficients using seven-wavelength aethalometer data, J. Aerosol Sci., 36, 267-282.

Flannigan, M., B. Stocks, and B. Wotton (2000), Climate change and forest fires, Sci. Total Environ., 262, 221-229.

Flocke, F., et al. (2005), Results from fast airborne measurements of PANs during the 2004 New England Air Quality Study, Eos Trans. AGU, 86(52), Fall Meet. Suppl., Abstract A54C-03

Forster, C., et al. (2001), Transport of boreal forest fire emissions from Canada to Europe, J. Geophys. Res., 106, 22,887-22,906.

Fromm, M., R. Bevilacqua, R. Servranckx, J. Rosen, J.P. Thayer, J. Herman, and D. Larko (2005), Pyro-cumulonimbus injection of smoke to the stratosphere: Observations and impact of a super blowup in northwestern Canada on 3-4 August 1998, J. Geophys. Res., 110, D08205, doi:10.1029/2004JD005350.

Gao, R. S., E. R. Keim, E. L. Woodbridge, S. J. Cicora, M. H. Proffitt, T. L. Thompson, R. J. Mclaughlin, and D. W. Fahey (1994), New photolysis system for $\mathrm{NO}_{2}$ measurements in the lower stratosphere, J. Geophys Res., 99, 20,673-20,681

Gillett, N., A. J. Weaver, F. W. Zwiers, and M. D. Flannigan (2004), Detecting the effect of climate change on Canadian forest fires, Geophys. Res. Lett., 31, L18211, doi:10.1029/2004GL020876.

Goode, J. G., R. J. Yokelson, D. E. Ward, R. A. Susott, R. E. Babbitt, M. A. Davies, and W. M. Hao (2000), Measurements of excess $\mathrm{O}_{3}$, $\mathrm{CO}_{2}, \mathrm{CH}_{4}, \mathrm{C}_{2} \mathrm{H}_{4}, \mathrm{C}_{2} \mathrm{H}_{2}, \mathrm{HCN}, \mathrm{NO}, \mathrm{NH}_{3}, \mathrm{HCOOH}, \mathrm{CH}_{3} \mathrm{COOH}$ $\mathrm{HCHO}$, and $\mathrm{CH}_{3} \mathrm{H}$ in 1997 Alaskan biomass burning plumes by airborne Fourier transform infrared spectroscopy (AFTIR) $\left[\mathrm{O}_{3} \mathrm{CO}_{2} \mathrm{CH}_{4}\right.$ $\left.\mathrm{C}_{2} \mathrm{H}_{4} \quad \mathrm{C}_{2} \mathrm{H}_{2} \quad \mathrm{NH}_{3} \mathrm{CH}_{3} \mathrm{COOH} \mathrm{CH}_{3} \mathrm{H}\right]$, J. Geophys. Res., 105(D17), $22,147-22,166$

Griffin, R. J., III, R. C. Flagan, and J. H. Seinfeld (1999), Organic aerosol formation from the oxidation of biogenic hydrocarbons, J. Geophys. Res. 104(D3), 3555-3568
Hansen, J., M. Sato, R. Ruedy, A. Lacis, and V. Oinas (2000), Global warming in the twenty-first century: An alternative scenario, Proc. Natl. Acad. Sci. U.S.A., 97, 9875-9880.

Hassol, S. J. (2004), Impacts of a Warming Arctic: Arctic Climate Impact Assessment, Cambridge Univ. Press, New York.

Honrath, R. E., R. C. Owen, M. Val Martín, J. S. Reid, K. Lapina, P. Fialho, M. P. Dziobak, J. Kleissl, and D. L. Westphal (2004), Regional and hemispheric impacts of anthropogenic and biomass burning emissions on summertime $\mathrm{CO}$ and $\mathrm{O}_{3}$ in the North Atlantic lower free troposphere, J. Geophys. Res., 109, D24310, doi:10.1029/2004JD005147.

Horowitz, L. W., et al. (2003), A global simulation of tropospheric ozone and related tracers: Description and evaluation of MOZART, version 2, J. Geophys. Res., 108(D24), 4784, doi:10.1029/2002JD002853.

Houghton, J. T., Y. Ding, D. J. Griggs, M. Noguer, P. J. van der Linden, X. Dai, K. Maskell, and C. A. Johnson (Eds.) (2001), Climate Change 2001: The Scientific Basis-Contribution of Working Group I to the Third Assessment Report of the Intergovernmental Panel on Climate Change, Cambridge Univ. Press, New York.

Jacob, D., et al. (1992), Summertime photochemistry of the troposphere at high northern latitudes, J. Geophys. Res., 97, 16,421-16,431.

Jaffe, D., I. Bertschi, L. Jaeglé, P. Novelli, J. S. Reid, H. Tanimoto, R. Vingarzan, and D. L. Westphal (2004), Long-range transport of Siberian biomass burning emissions and impact on surface ozone in western North America, Geophys. Res. Lett., 31, L16106, doi:10.1029/2004GL020093.

Jain, A. K., Z. Tao, X. Yang, and C. Gillespie (2006), Estimates of global biomass burning emissions for reactive greenhouse gases $(\mathrm{CO}, \mathrm{NMHCs}$, and $\mathrm{NO}_{\mathrm{x}}$ ) and $\mathrm{CO}_{2}, J$. Geophys. Res., 111, D06304, doi:10.1029/ 2005JD006237.

Kasischke, E. S., and M. R. Turetsky (2006), Recent changes in the fire regime across the North American boreal region-Spatial and temporal patterns of burning across Canada and Alaska, Geophys. Res. Lett., 33 , L09703, doi:10.1029/2006GL025677.

Kasischke, E. S., E. J. Hyer, P. C. Novelli, L. P. Bruhwiler, N. H. F. French, A. I. Suckhinin, J. H. Hewson, and B. J. Stocks (2005), Influences of boreal fire emissions on Northern Hemisphere atmospheric carbon and carbon monoxide, Global Biogeochem. Cycles, 19, GB1012, doi:10.1029/2004GB002300.

Kleissl, J., et al. (2006), The occurrence of upslope flows at the Pico mountain-top observatory: A case study of orographic flows on a small, volcanic island, J. Geophys. Res., doi:10.1029/2006JD007565, in press.

Kley, D., and M. McFarland (1980), Chemiluminescence detector for NO and $\mathrm{NO}_{2}$, Atmos. Technol., 12, 63-69.

Kliner, D., B. Daube, J. Burley, and S. Wofsey (1997), Laboratory investigation of the catalytic reduction technique for measurement of atmospheric $\mathrm{NO}_{y}$, J. Geophys. Res., 102, 10,759-10,776

Kondo, Y., et al. (1997), Profiles and partitioning of reactive nitrogen over the Pacific Ocean in winter and early spring, J. Geophys. Res., 102 , $28,405-28,424$

Lapina, K., R. E. Honrath, R. C. Owen, M. Val Martín, and G. Pfister (2006), Evidence of significant large-scale impacts of boreal fires on ozone levels in the midlatitude Northern Hemisphere free troposphere, Geophys. Res. Lett., 33, L10815, doi:10.1029/2006GL025878.

Li, Q., D. J. Jacob, J. W. Munger, R. M. Yantosca, and D. D. Parrish (2004), Export of NOy from the North American boundary layer: Reconciling aircraft observations and global model budgets, J. Geophys. Res., 109, D02313, doi:10.1029/2003JD004086.

Liang, J., L. W. Horowitz, D. J. Jacob, Y. Wang, A. M. Fiore, J. A. Logan, G. M. Gardner, and J. W. Munger (1998), Seasonal budgets of reactive nitrogen species and ozone over the United States and export fluxes to the global atmosphere, J. Geophys. Res., 103, 13,435-13,450.

Mauzerall, D. L., D. J. Jacob, S. M. Fan, J. D. Bradshaw, G. L. Gregory, G. W. Sachse, and D. R. Blake (1996), Origin of tropospheric ozone at remote high northern latitudes in summer, J. Geophys. Res., 101, 41754188

Mauzerall, D. L., et al. (1998), Photochemistry in biomass burning plumes and implications for tropospheric ozone over the tropical South Atlantic, J. Geophys. Res., 103, 8401-8423.

McKeen, S. A., G. Wotawa, D. D. Parrish, J. S. Holloway, M. P. Buhr, G. Hbler, F. C. Fehsenfeld, and J. F. Meagher (2002), Ozone production from Canadian wildfires during June and July of 1995, J. Geophys. Res., 107(D14), 4192, doi:10.1029/2001JD000697.

Mollicone, D., H. Eva, and F. Achard (2006), Human role in Russian wild fires, Nature, 440, 436-437, doi:10.1038/440436a

Morris, G., et al. (2006), Alaskan and Canadian forest fires exacerbate ozone pollution over Houston, Texas, on 19 and 20 July 2004, J. Geophys. Res., 111, D24S03, doi:10.1029/2006JD007090.

Novelli, P. C., L. P. Steele, and P. P. Tans (1992), Mixing ratios of carbon monoxide in the troposphere, J. Geophys. Res, 97, 20,731-20,750.

Novelli, P. C., K. A. Masarie, P. M. Lang, B. D. Hall, R. C. Myers, and J. W. Elkins (2003), Reanalysis of tropospheric CO trends: Effects of the 
1997-1998 wildfires, J. Geophys. Res., 108(D15), 4464, doi:10.1029/ 2002JD003031.

Owen, R. C., O. R. Cooper, A. Stohl, and R. E. Honrath (2006), An analysis of the mechanisms of North American pollutant transport to the central North Atlantic lower free troposphere, J. Geophys. Res., 111, D23S58, doi:10.1029/2006JD007062.

Park, R. J., et al. (2005), Export efficiency of black carbon aerosol in continental outflow: Global implications, J. Geophys. Res., 110 D11205, doi:10.1029/2004JD005432.

Parrish, D. D., et al. (1990), Systematic variations in the concentration of $\mathrm{NO}_{x}\left(\mathrm{NO}\right.$ plus $\mathrm{NO}_{2}$ ) at Niwot Ridge, Colorado, J. Geophys. Res., 95, $1817-1836$.

Parrish, D. D., J. S. Holloway, and F. C. Fehsenfeld (1994), Routine, continuous measurement of carbon monoxide with parts per billion precision, Environ. Sci. Technol., 28, 1615-1618.

Parrish, D. D., M. Trainer, J. S. Holloway, J. E. Yee, M. S. Warshawsky, F. C. Fehsenfeld, G. Forbes, and J. L. Moody (1998), Relationships between ozone and carbon monoxide at surface sites in the North Atlantic region, J. Geophys. Res., 103, 13,357-13,376.

Parrish, D. D., et al. (2004), Fraction and composition of $\mathrm{NO}_{y}$ transported in air masses lofted from the North American boundary layer, J. Geophys. Res., 109, D09302, doi:10.1029/2003JD004226.

Peterson, M. C., and R. E. Honrath (1999), $\mathrm{NO}_{x}$ and $\mathrm{NO}_{y}$ over the northwestern North Atlantic: Measurements and measurement accuracy, J. Geophys. Res., 104, 11,695-11,707.

Pfister, G., P. G. Hess, L. K. Emmons, J.-F. Lamarque, C. Wiedinmyer, D. P. Edwards, G. Ptron, J. C. Gille, and G. W. Sachse (2005), Quantifying CO emissions from the 2004 Alaskan wildfires using MOPITT CO data, Geophys. Res. Lett., 32, L11809, doi:10.1029/2005GL022995.

Pfister, G., et al. (2006), Ozone production from boreal forest fire emissions, J. Geophys. Res., doi:10.1029/2006JD007565, in press.

Reid, J. S., R. Koppmann, T. F. Eck, and D. P. Eleuterio (2005), A review of biomass burning emissions part II: Intensive physical properties of biomass burning particles, Atmos. Chem. Phys., 5, 799-825.

Ridley, B. A., and F. E. Grahek (1990), A small, low flow, high sensitivity reaction vessel for $\mathrm{NO}$ chemiluminescence detectors, J. Atmos. Technol., 7, 307-311.

Sandholm, S. T., et al. (1992), Summertime tropospheric observations related to $\mathrm{N}_{\mathrm{x}} \mathrm{O}_{\mathrm{y}}$ distributions and partitioning over Alaska: Arctic Boundary Layer Expedition 3A, J. Geophys. Res., 97(D15), 16,481-16,509.

Simmonds, P. G., A. J. Manning, R. G. Derwent, P. Ciais, M. Ramonet, V. Kazan, and D. Ryall (2005), A burning question. Can recent growth rate anomalies in the greenhouse gases be attributed to large-scale biomass burning events?, Atmos. Environ., 39, 2513-2517, doi:10.1016 j.atmosenv.2005.02.018.
Singh, H. B., et al. (1994), Summertime distribution of PAN and other reactive nitrogen species in the northern high-latitude atmosphere of eastern Canada, J. Geophys. Res, 99, 1821-1835.

Stocks, B., et al. (1998), Climate change and forest fire potential in Russian and Canadian boreal forests, Clim. Change, 38, 1-13.

Stohl, A., M. Trainer, T. B. Ryerson, J. S. Holloway, and D. D. Parrish (2002), Export of NOy from the North American boundary layer during 1996 and 1997 North Atlantic Regional Experiments, J. Geophys. Res., 107(D11), 4131, doi:10.1029/2001JD000519.

Stohl, A., C. Forster, A. Frank, P. Seibert, and G. Wotawa (2005), Technical note: The Lagrangian particle dispersion model FLEXPART version 6.2, Atmos. Chem. Phys., 5, 2461-2474.

Stohl, A., et al. (2006), Pan-Arctic enhancements of light absorbing aerosol concentrations due to North American boreal forest fires during summer 2004, J. Geophys. Res., doi:10.1029/2006JD007216, in press.

Talbot, R. W. (1994), Summertime distribution and relations of reactive odd nitrogen species and $\mathrm{NO}_{y}$ in the troposphere over Canada, J. Geophys. Res., 99, 1863-1885.

Tanimoto, H., Y. Kajii, J. Hirokawa, H. Akimoto, and N. P. Minko (2000), The atmospheric impact of boreal forest fires in far eastern Siberia on the seasonal variation of carbon monoxide: Observations at Rishiri, a northern remote island in Japan, Geophys. Res. Lett., 27(24), 4073-4076.

Wofsy, S. C., et al. (1992), Atmospheric chemistry in the Arctic and subarctic: Influence of natural fires, industrial emissions, and stratospheric inputs, J. Geophys. Res., 97, 16,731-16,746.

Wofsy, S. C., S.-M. Fan, D. R. Blake, J. D. Bradshaw, S. T. Sandholm, H. B. Singh, G. W. Sachse, and R. C. Harriss (1994), Factors influencing atmospheric composition over subarctic North America during summer, J. Geophys. Res., 99, 1887-1897.

Wotawa, G., and M. Trainer (2000), The influence of Canadian forest fires on pollutant concentrations in the United States, Science, 288(5464), $324-328$.

Yokelson, R. J., D. W. T. Griffith, and D. E. Ward (1996), Open-path fourier transform infrared studies of large-scale laboratory biomass fires, J. Geophys. Res., 101(D15), 21,067-21,080.

F. Barata and P. Fialho, Group of Chemistry and Physics of the Atmosphere, University of the Azores, Terra Chã PT-9701-851, Portugal.

R. E. Honrath, R. C. Owen, and M. Val Martín, Department of Civil and Environmental Engineering, Michigan Technological University, Houghton, MI 49931, USA. (mvalmart@mtu.edu)

G. Pfister, Atmospheric Chemistry Division, National Center for Atmospheric Research, Boulder, CO 80307, USA. 